\title{
Genetic polymorphisms and metabolism of endocrine disruptors in cancer susceptibility
}

\author{
Polimorfismos genéticos e metabolismo \\ dos desreguladores endócrinos \\ na suscetibilidade ao câncer
}

Ana Hatagima 1

\footnotetext{
1 Laboratório de Genética Humana, Departamento de Genética, Instituto Oswaldo Cruz, Fundação Oswaldo Cruz. Av. Brasil 4365 Pavilhão Leônidas Deane, 6 o andar, Rio de Janeiro, $R J$ 21045-900, Brasil. anah@ioc.fiocruz.br
}

\begin{abstract}
Epidemiological studies have estimated that approximately $80 \%$ of all cancers are related to environmental factors. Individual cancer susceptibility can be the result of several host factors, including differences in metabolism, DNA repair, altered expression of tumor suppressor genes and proto-oncogenes, and nutritional status. Xenobiotic metabolism is the principal mechanism for maintaining homeostasis during the body's exposure to xenobiotics. The balance of xenobiotic absorption and elimination rates in metabolism can be important in the prevention of DNA damage by chemical carcinogens. Thus the ability to metabolize and eliminate xenobiotics can be considered one of the body's first protective mechanisms. Variability in individual metabolism has been related to the enzymatic polymorphisms involved in activation and detoxification of chemical carcinogens. This paper is a contemporary literature review on genetic polymorphisms involved in the metabolism of endocrine disruptors potentially related to cancer development.
\end{abstract}

Key words Neoplasms; Polymorphism (Genetics); Xenobiotic; Endocrine Disruptors

Resumo Estudos epidemiológicos estimam que cerca de $80 \%$ dos cânceres estão relacionados a fatores ambientais. A suscetibilidade individual ao câncer pode resultar de vários fatores relacionados ao metabolismo de xenobióticos, reparo do DNA, expressão de genes supressores de tumor e protoncogenes e estado nutricional. O metabolismo é o principal mecanismo para manter a homeostasia durante a exposição dos organismos aos xenobióticos. O equilíbrio das taxas de absorção e eliminação dos xenobióticos tem um papel importante na prevenção de danos no DNA, provocados por carcinógenos químicos. Sendo assim, a habilidade de metabolizar e eliminar os xenobióticos pode ser considerada uma das primeiras linhas de defesa dos organismos. Variações no metabolismo individual têm sido relacionadas aos polimorfismos enzimáticos, envolvidos na ativação e desintoxicação de carcinógenos químicos. Neste trabalho, é realizada uma revisão da literatura contemporânea sobre os polimorfismos genéticos envolvidos no metabolismo de desreguladores endócrinos, potencialmente associados ao desenvolvimento do câncer. Palavras-chave Neoplasias; Polimorfismos (Genética); Xenobióticos; Desreguladores Endócrinos 


\section{Introduction}

Xenobiotics are natural or artificial chemical substances that are alien to the body, such as drugs, industrial products, pesticides, pollutants, alkaloids, metabolites of secondary plants, and toxins produced by fungi, plants, and animals (Parkinson, 1996), many of them acting as endocrine disruptors. In their natural or biotransformed state, xenobiotics can affect DNA integrity, leading to cancer if exposure persists. Accumulated DNA damage, added to spontaneous replication errors not corrected by the repair system, can cause irreversible mutations which in turn can lead to the development of tumors and/or progression of cancer. Epidemiological studies show that $80-90 \%$ of all cancers are related to environmental factors like smoking and occupational and dietary exposures (Doll \& Peto, 1981). Thus, the individual capacity to biotransform toxic into non-toxic xenobiotics can be considered the first line of defense in the process characterized by successive stages of transformation of potentially toxic chemical substances as a pathway towards their subsequent elimination. The enzymes involved are frequently the ones that determine the intensity and duration of the action of drugs and other xenobiotics, hence their importance in chemical and carcinogenic toxicity. Biotransformation of xenobiotics involves the modification of their physical properties, generally from lipophilic (easily absorbed) to hydrophilic, facilitating their excretion. Otherwise, many lipophilic xenobiotics would be excreted so slowly that they would eventually accumulate, destroying the organism by making it biologically nonviable (Parkinson, 1996). The same can happen when the absorption rate exceeds that of elimination. This imbalance can jeopardize the body's homeostasis and the accumulation of certain drugs, for example, can have toxic consequences of a pharmacological, pathological, or genotoxic nature. An example of pharmacological toxicity is the central nervous system depression caused by barbiturates; a pathological effect is the kidney involvement in mercury poisoning and an example of a genotoxic effect is cancer caused by mustard gas.

Biotransformation involves two stages: phase I, mainly involving enzymatic activity from the cytochrome P450 (CYP) family; and phase II, catalyzed by conjugation enzymes like glutathione S-transferase (GST), UDP-glucuronosyltransferase, and $\mathrm{N}$-acetyltransferase (NAT). Most carcinogenic chemical products are not toxic per se and require metabolic activation before interacting with cellular macro- molecules. Phase I enzymes promote the activation of drugs and pro-carcinogens for the genotoxic electrophilic intermediaries. Meanwhile, phase II enzymes generally act as inactivating enzymes, that is, they catalyze the binding of intermediary metabolites to cofactors, transforming them into more hydrophilic products, thus facilitating their elimination (Raunio et al., 1995). Therefore, the coordinated expression and regulation of xenobiotic metabolizing enzymes (XMEs) in both phase I and phase II and their metabolic equilibrium in the cells of target organs can be important factors in determining susceptibility to cancer as related to exposure to carcinogens (Kawajiri et al., 1993).

Mutations in these genes can produce defective, partially defective enzymes or ones with altered specificities to the substrates, and thus there may or may not be the production of functional proteins or even enzymes with different levels of activities. The combination of the alleles from these genes can cause an increase or decrease in the susceptibility to certain toxic agents or environmental carcinogens. There are marked interindividual and interethnic differences in the capacity to metabolize drugs and other xenobiotics. This variation is due to the polimorphisms in the corresponding genes and to physiological, pathological, and environmental factors (Ingelman-Sundberg, 1998).

Interindividual variability in xenobiotic metabolism has been associated with greater or lesser susceptibility to toxicity or cancer risk in response to the same exposure to a given environmental pollutant. Thus, individuals incapable of adequately detoxifying a metabolic carcinogen or toxic agent due to reduced enzymatic activity would undergo more DNA and cell damage with the formation of adducts, or chemical elements bound to the DNA and protein macromolecules, genomic instability, and consequently would have a greater risk of developing toxicity or cancer (Raunio et al., 1995).

Increasing attention has been focused on our knowledge of variations in susceptibility to diseases within a population and the identification of risk factors so as to orient preventive policies. The literature has shown that variability in the expression of genes for XMEs (xenobiotic metabolizing enzymes) suggests an influence on the biological response to carcinogens. Despite displaying weak indication of risk at the individual level due to association with various other factors, gene polymorphisms (principally those influencing the metabolic activation or detoxification of carcinogenic chemical products) can be important factors for susceptibility at the population level (Perera, 1997). 
Molecular epidemiology has made great progress in detecting many human gene polymorphisms in XMEs, and some have shown to be correlated to increased risk of cancer. Not all the enzymes involved in phase I and II biotransformation are part of the detoxification process. For example, some microsomal and mitochondrial P450 enzymes play a relevant role in the biosynthesis of steroid hormones, biliary acids, fat-soluble vitamins, fatty acids, etc. This paper focuses on just a few genetic polymorphisms that have been investigated more extensively due to their association with cancer, like genes from the cytochrome P450 (CYP1A1, CYP2E1, and CYP2D6) and glutathione S-transferase (GSTM1, GSTM3, GSTP1, and GSTT1) families.

\section{Cytochrome P450 genes (CYPs)}

The human cytochrome P450 superfamily comprises at least ten known and characterized families and numerous sub-families (Nebert, 1991). During biotransformation, cytochrome P450 mediates the phase I reactions in which xenobiotics are detoxified or activated to reactive intermediate substances. The highest concentration of these enzymes has been observed in the liver endoplasmic reticulum (microsomes), but they are present in all tissues in a tissue-specific manner. In the liver, they determine the intensity and duration of drug action and promote the detoxification of xenobiotics. They also catalyze the activation of xenobiotics to toxic and/or carcinogenic metabolites in both the liver and extra-hepatic tissues.

The contribution of each P450 enzyme to the activation of carcinogens has been extensively evaluated, and this research has shown that most environmental carcinogens are activated principally by a limited number of them, including the following: CYP1A1, CYP1A2, CYP2E1, CYP2D6, and CYP3A (Kawajiri et al., 1993). Many are polymorphic, displaying different metabolic activities, reflected in adverse toxic effects, including carcinogenesis induced by endogenous chemical substances (Autrup, 2000).

\section{CYP1A1}

This gene belongs to the CYP1 sub-family and encodes for the enzyme aryl hydrocarbon hydroxylase $(\mathrm{AHH})$, which catalyzes the first step in the metabolism of polycyclic aromatic hydrocarbons, such as those found in cigarette smoke, transforming them into carcinogens.
The observation of a trimodal pattern of inducibility in AHH suggests that CYP1A1 is genetically regulated (Kellermann et al., 1973; Trell et al., 1985). Individuals with CYP1A1 gene inducibility or high levels of $\mathrm{AHH}$ enzymatic activity can be more susceptible to the carcinogens present in cigarette smoke and to the development of lung cancer induced by these agents.

The CYP1Al gene is located in chromosome 15, band 15q22-24 (Hildebrand et al., 1985) and various patterns in restriction fragment length polymorphism (RFLP) for this gene have been reported. An Msp I RFLP was identified in the 3' flanking region of the CYP1A1 gene (Kawajin et al., 1990). This mutation determines three different genotypes, called $\mathrm{m} 1 / \mathrm{ml}$, which is homozygotes for the wild type allele and does not have the restriction site for Msp I, $\mathrm{m} 1 / \mathrm{m} 2$, and $\mathrm{m} 2 / \mathrm{m} 2$, which are, respectively, the heterozygotes and the homozygotes for the mutant allele and which have the site for Msp I. Individuals with the mutant allele display increased AHH activity. A second point mutation, a transversion in position 4889 in exon 7, was described and linked to Msp I. This mutation leads to a isoleucine/valine substitution in exon 7 and is known as Ile-Val or exon 7 polymorphism (Hayashi et al., 1991a). The Ile/Ile genotype corresponds to the wild type and Ile/Val and $\mathrm{Val} / \mathrm{Val}$ to the heterozygous and homozygous genotypes for the mutant allele, respectively. Its function has still not been completely defined, and may depend on its link to the $M s p$ $I$ polymorphism or to other polymorphisms that can affect the CYP1A1 transcription levels, such as polymorphisms for promoter genes, AHR (Ah receptor) genes, or other metabolic genes (Crofts et al. 1994). The exon 7 mutation has been associated with both an increase in the inducibility and activity of the CYP1A1 enzyme (Crofts et al. 1994). A third polymorphism with no link to the previous two was found in African-American populations (AA polymorphism), and its functional consequences remain to be defined (Crofts et al., 1993). Finally, the polymorphism involving a transversion in position 4887 of exon 7, was described by Cascorbi et al. (1996). Its frequency is ten times higher in Caucasians than in African-Americans $(4.0 \%$ vs $0.4 \%$, respectively), and its functional effect also remains to be determined.

\section{- CYP1A1 and cancer susceptibility}

Kouri et al. (1982) observed a positive correlation between AHH enzyme activity and lung cancer. Since then, various association studies 
have been conducted in different populations, seeking a correlation between the mutant genotype and different types of cancer (Table 1).

A correlation between CYP1A1 polymorphism (Msp I) and lung cancer susceptibility was observed in the Japanese (Hayashi et al., 1992; Kawajiri et al., 1990, 1993; Nakachi et al., 1991) and Hawaiians (Le Marchand et al., 1998), but not in Caucasians or African Americans (Hirvönen et al., 1992; Shields et al., 1993; Tefre et al., 1991). The suggested explanation for this discrepancy is that it reflects different frequencies of mutant alleles in the various ethnic groups (Cosma et al., 1993). However, a case-control study on lung cancer in Rio de Janeiro by Sugimura et al. (1995) found the same association with CYP1A1 observed by Kawajiri et al. (1990). More recently, Xu et al. (1996) also demonstrated a significant association between CYP1A1 polymorphisms (Msp I) and lung cancer risk in the U.S. population, even after excluding non Caucasians from the analysis. According to these authors, the Msp I CYP1A1 variant promotes an increased risk of lung cancer in both Japanese and Caucasians.

Nakachi et al. (1993), studying squamous cell carcinoma in Japanese smokers, observed an increased risk among individuals with the CYP1A1 (m2/m2) genotype combined with the GSTM1 null genotype. The same was observed in Hawaiians by Le Marchand et al. (1998). In a similar study, Kihara et al. (1995) also observed that the frequency of CYP1A1 $(\mathrm{m} 2 / \mathrm{m} 2)$ did not differ between patients and controls who smoked, but that the frequency of individuals carrying genotype CYP1A1(m2/m2) and GSTM1 null was greater among patients than controls. When they estimated the odds ratio, they observed that CYP1A1 $(\mathrm{m} 2 / \mathrm{m} 2)$ and GSTM1 positive individuals were associated with a lower risk of developing tumors than individuals with genotype CYP1A1(m2/m2) and GSTM1 null. These results suggest that genotype CYP1A1 $(\mathrm{m} 2 / \mathrm{m} 2)$ promotes a relative resistance to lung cancer when combined with GSTM1 positive, but susceptibility when combined with GSTM1 null. Kihara et al. (1995) also suggest that the combination of these two polymorphisms may be a good marker for predicting tobacco-related lung cancer risk in populations like the Japanese in which the CYP1A1 (m2/m2) allele is common. However, Matthias et al. (1998), studying cancer of the upper aerodigestive tract, did not observe differences in the genotypic distribution of polymorphisms CYP1A1, CYP2E1, and CYP2D6.

Sivaraman et al. (1994), studying different ethnic groups, observed that genotype CYP1A1
Msp I (m2/m2) was significantly associated with the risk of colorectal cancer in Japanese and Hawaiians, but not in Caucasians. Once again the results show that this effect is more difficult to reproduce in Caucasians due to the low frequency of the $\mathrm{m} 2$ allele and also the need for very large samples in population studies when the frequency of the mutant allele is low.

Based on the knowledge that estrogen metabolism is in part determined by CYP1A1, Taioli et al. (1995) studied the role of CYP1A1 in breast cancer susceptibility among Caucasian and African American women. No association was found with the Msp I polymorphism in Caucasian women, but in African American women the $\mathrm{m} 2 / \mathrm{m} 2$ genotype was associated with this cancer. According to the authors, the mechanisms in this association are still unknown, but there may be a link between the Msp I polymorphism and other polymorphisms related to breast cancer in the African American population. A study by Bailey et al. (1998) using a larger population sample failed to confirm this association.

In relation to the exon 7 polymorphism in the CYP1Al gene, the $\mathrm{G}$ allele appears to be associated with increased risk of lung cancer (Hamada et al., 1995; Sugimura et al., 1998) and oral cancer (Park et al., 1997), suggesting that this polymorphism may be responsible for individual susceptibility in these cases. However, in some studies no significant differences were observed in the genotype distribution between controls and cases of esophageal (Morita et al., 1997), colorectal (Sivaraman et al., 1994), and head and neck cancer (Olshan et al., 2000). Park et al. (1997) observed that individuals with genotype CYP1A1 (ile/val) had a greater risk of oral cancer and that this was not influenced by different levels of exposure to tobacco. However, Tanimoto et al. (1999) observed a strong association between the Msp I polymorphism and oral cancer in individuals with low levels of cigarette consumption. This association is consistent with high levels of the CYP1Al enzyme in the oral tissue (Romkes et al., 1996). In addition, Sato et al. (2000) observed a greater risk of oral squamous cell cancer (SCC) in individuals with genotype CYP1A1 (val/val) combined with GSTM1 null, particularly at low levels of tobacco exposure. The discrepancy in these results has prompted research on these polymorphisms in different ethnic groups and types of cancer. In addition, it shows the importance of sample size (when the frequency of the mutant alleles is low), ethnic differences, environmental exposures, and gene-gene and gene-environment interactions. 
CYP1A1 polymorphism in selected cancer sites (literature review).

\begin{tabular}{|c|c|c|c|c|c|}
\hline Authors & $\begin{array}{l}\text { Gene or } \\
\text { combined genes }\end{array}$ & Polymorphism & $\begin{array}{l}\text { Country/State/ } \\
\text { ethnic group }\end{array}$ & Cancer site & Results \\
\hline Kawajiri et al. (1990) & CYP1A1 & RFLP-Msp I & Japan & Lung & $\begin{array}{l}\mathrm{LC}: \mathrm{OR}=3.1(\mathrm{Cl} \text { not given }) \\
\mathrm{SCC}: \mathrm{OR}=4.6(\mathrm{Cl} \text { not given })\end{array}$ \\
\hline Hayashi et al. (1992) & CYP1A1 & RFLP-Msp I & Japan & Lung & $\begin{array}{l}\text { CYP1A1; OR = } 2.97(1.59-5.57) \text { in LC } \\
\text { CYP1A1 val/val and GSTT1 null; } \\
\text { OR }=5.83(2.28-13.3) \text { in LC } \\
\text { CYP1A1 val/val and GSTT1 null; } \\
\text { OR }=9.07(3.38-24.4) \text { in SCC }\end{array}$ \\
\hline Nakachi et al. (1991) & CYP1A1 & RFLP-Msp I & Japan & Lung/SCC & $\begin{array}{l}\text { OR }=7.31(2.13-25.12) \text { (group with } \\
\text { low-dose smoking) }\end{array}$ \\
\hline Le Marchand et al. (1998) & CYP1A1-GSTM1 & $\begin{array}{l}\text { RFLP-Msp I, } \\
\text { GSTM100 }\end{array}$ & Hawaii, USA & Lung/SCC & $\begin{array}{l}\text { CYP1A1; OR = } 2.4(1.2-4.7) \\
\text { CYP1A1 (m2/-) and GSTM1 00; } \\
\text { OR = 3.1 (1.2-7.9) }\end{array}$ \\
\hline Tefre et al. (1991) & CYP1A1 & RFLP-Msp I & Norway & Lung & NS (OR not given) \\
\hline Hirvonen et al. (1992) & CYP1A1 & RFLP-Msp I & Finland & Lung & NS (OR not given) \\
\hline Shields et al. (1993) & CYP1A1 & RFLP-Msp I & USA & Lung & NS (OR not given) \\
\hline Sugimura et al. (1995) & CYP1A1 & RFLP-Msp I & Brazil & Lung & $\mathrm{OR}=2.4(1.15-4.98)$ \\
\hline Xu et al. (1996) & CYP1A1 & RFLP-Msp I & USA & Lung & $\mathrm{OR}=2.08(1.15-3.73)$ \\
\hline Nakachi et al. (1993) & CYP1A1-GSTM1 & $\begin{array}{l}\text { RFLP-Msp I and } \\
\text { Exon 7, GSTM1 } 00\end{array}$ & Japan & Lung & $\begin{array}{l}\text { CYP1A1(Msp I) and GSTM1 00; } \\
\text { OR = } 16.0(3.76-68.02) \\
\text { CYP1A1(ile/val) and GSTM1 00; } \\
\text { OR = 41.0 (8.68-193.61) }\end{array}$ \\
\hline Kihara et al. (1995) & CYP1A1-GSTM1 & $\begin{array}{l}\text { RFLP-Msp I, } \\
\text { GSTM100 }\end{array}$ & Japan & Lung & $\begin{array}{l}\text { CYP1A } 1(\mathrm{~m} 2 / \mathrm{m} 2) \text { and GSTM } 100 \\
(81.3 \% \text { in patients vs } 39.4 \% \text { in } \\
\text { controls, } \mathrm{p}<0.01)\end{array}$ \\
\hline Mathias et al. (1998) & CYP1A1 & $\begin{array}{l}\text { RFLP-Msp I, } \\
\text { Exon } 7\end{array}$ & $\begin{array}{l}\text { Germany } \\
\text { (Caucasians) }\end{array}$ & $\begin{array}{l}\text { Upper } \\
\text { aerodigestive } \\
\text { tract }\end{array}$ & $\begin{array}{l}\text { CYP1A1 m1/m1; OR = } 0.7(0.7-2.7) \\
\text { CYP1A1 ile/ile1; OR }=1.3(0.3-1.3)\end{array}$ \\
\hline Sivaraman et al. (1994) & CYP1A1 & RFLP-Msp I & $\begin{array}{l}\text { Japan and } \\
\text { Hawaii, USA }\end{array}$ & Colorectal & $\mathrm{OR}=7.9(1.4-44.4)$ \\
\hline Taioli et al. (1995) & CYP1A1 & RFLP-Msp I & $\begin{array}{l}\text { USA (Caucasians } \\
\text { and African } \\
\text { Americans) }\end{array}$ & Breast & $\begin{array}{l}\text { OR }=9.7(2.0-47.9) \text { (only in African } \\
\text { Americans) }\end{array}$ \\
\hline Bailey et al. (1998) & CYP1A1 & RFLP-Msp I & $\begin{array}{l}\text { USA (Caucasians } \\
\text { and African } \\
\text { Americans) }\end{array}$ & Breast & $\begin{array}{l}O R=1.37(0.78-2.41) \text { Caucasians } \\
O R=0.51(0.24-1.10) \text { African } \\
\text { Americans }\end{array}$ \\
\hline Hamada et al. (1995) & CYP1A1 & Exon 7 & Japan & Lung & $\mathrm{OR}=2.26(1.14-4.47)$ \\
\hline Sugimura et al. (1998) & CYP1A1 & Exon 7 & Japan & Lung & $\mathrm{OR}=3.3(1.3-8.6)$ \\
\hline Park et al. (1997) & CYP1A1 & Exon 7 & USA (Caucasians) & Oral & $\mathrm{OR}=2.6(1.2-5.7)$ \\
\hline Morita et al. (1997) & CYP1A1 & Exon 7 & Japan & Esophageal & $\mathrm{OR}=1.0(0.5-1.9)$ \\
\hline Olshan et al. (2000) & CYP1A1-GSTM1 & Exon 7 & & Head and neck & $\mathrm{OR}=2.6 ; \mathrm{Cl}: 0.7-10.3$ \\
\hline Tanimoto et al. (1999) & CYP1A1 & RFLP-Msp I & Japan & Oral & $\begin{array}{l}\text { OR }=3.6(1.4-9.5) \text { (at low-dose } \\
\text { smoking levels) }\end{array}$ \\
\hline Sato et al. (2000) & CYP1A1 & Exon 7 & Japan & $\begin{array}{l}\text { Oral squamous } \\
\text { cell carcinoma } \\
\text { (SCC) }\end{array}$ & $\begin{array}{l}\text { CYP1A1 (ile/val) and GSTM1 00; } \\
\text { OR = } 3.9 \text { (1.6-9.7) } \\
\text { CYP1A1 (val/val) and GSTM1 00; } \\
\text { OR = } 28.5 \text { (3.3-248) (at low-dose } \\
\text { smoking levels) }\end{array}$ \\
\hline
\end{tabular}

NS $=$ Not significant, OR = Odds ratio, LC = Lung cancer, SCC = Squamous cell carcinoma, RFLP = Restriction fragment length polymorphism. 


\section{CYP2E1}

The CYP2E1 gene belongs to the CYP2 family and encodes the enzyme $\mathrm{N}, \mathrm{N}$-dimethylnitrosamino- $\mathrm{N}$-dimethylase, which catalyzes the oxidation of many low molecular weight procarcinogens like benzene, styrene, and the nitrosamines. This enzyme is also involved in the metabolism of ethanol and acetone (González et al., 1998; Hayashi et al., 1991b) and can be induced by isoniazide and ethanol. It is present in various tissues, including the brain and lung, but its greatest expression occurs in the liver. CYP2E1 has a clear toxicological role, since it activates pro-carcinogens, organic solvents, and drugs, converting them into cytotoxic or carcinogenic products and potentiating the toxicity of solvents and drugs (Nedelcheva et al., 1996).

The CYP2E1 gene was mapped in region 10q24.3-qter of chromosome 10 (Kolble, 1993; Okino et al., 1987). Restriction fragment length polymorphism (RFLP) analysis revealed detectable polymorphisms through endonucleases Taq I, Dra I, Rsa I, Xmn I, and Msp I, and two principal sites were studied in correlation with diseases. These sites are located in region 5', approximately $1020 \mathrm{bp}$ upstream, where RFLP analysis revealed alleles $\mathrm{c} 1$ and $\mathrm{c} 2$. The wild allele cl presents a restriction site for Rsa I (RsaI+). Allele c2 results from a mutation (a G/C substitution), losing the restriction site to Rsa I (RsaI-), creating a site for the enzyme Pst I (Hayashi et al., 1991b). These sites are in linkage disequilibrium. Interest in these sites stemmed from observations on the possible association with induction of the gene (Nedelcheva et al., 1996). The polymorphisms affect its link to a transcription factor, altering its transcriptional regulation and may lead to inter-individual differences in the microsomal oxidation activity for drugs and other xenobiotics (Hayashi et al., 1991b). The c2 allele form binds the transcription factors to the mutation region less efficiently, suggesting that the gene is less expressed in vivo in individuals carrying this allele. Frequency of this allele is relatively low in different populations, for example $5 \%$ in Caucasians (Persson et al., 1993).

\section{- CYP2E1 and cancer susceptibility}

The CYP2E1 polymorphism has been related to lung (El-Zein et al., 1997; Persson et al., 1993), esophagus (Lin et al., 1998), and oral cancer (Hung et al., 1997) (Table 2). The presence of CYP2E1 as the predominant isoform in the breast is also an interesting finding, since it has been demonstrated that alcohol consumption is related to breast cancer (Hellmold et al., 1998).

Hung et al. (1997) observed an association between the mutant allele $\mathrm{c} 2$ (genotypes c1c2 and c2c2) and a significantly increased risk of oral cancer in a population in Taiwan. The frequencies of these genotypes were $51.2 \%$ and $37.4 \%$ in cases and controls, respectively. Alcohol consumption was also associated with a significantly increased risk of this type of cancer in this population, suggesting that gene-environment interactions were influencing oral carcinogenesis. Meanwhile, Tan et al. (2000) observed that genotype CYP2E1 (clcl) was associated with increased risk of esophageal cancer. The reasons for these discrepancies are not clear, but the authors suggest that ethnic differences in allele frequencies and specific exposures associated with polymorphisms should be considered.

Hirvönen et al. (1993) also observed differences in genotype distribution in lung cancer cases and controls. However, the risk related to the mutant genotype was not significantly greater in this type of cancer. Sugimura et al. (1995) also failed to find an association between the CYP2E1 Rsa I polymorphism and lung cancer in Rio de Janeiro, but the inter-ethnic difference reported by Kato et al. (1992) was corroborated, since the prevalence of homozygosity for absence of the Rsa I site was much lower than among the Japanese.

\section{CYP2D6}

The CYP2D6 gene belongs to the CYP2 family and was mapped in human chromosome 22, band 22q13.1 (Gough et al., 1993). Enzyme CYP2D6 (debrisoquine-4-hydroxylase) metabolizes debrisoquine and at least 80 other drugs, like antidepressants, neuroleptics, many antiarrhythmics, and lipophilic $\beta$-blockers (Ayesh et al., 1984; Autrup, 2000; Bertilsson, 1995). In addition to these substrates, CYP2D6 also acts on the carcinogen nitrosamine NNK (4-methylnitrosamino-1(3-pyridyl)-1-butanone), a component of cigarette smoke (Crespi et al., 1991). The absence of debrisoquine-4-hydroxylase activity can have serious clinical consequences and even lead to death, since usual doses can cause high plasma levels of the drug, leading to side effects (Bertilsson, 1995). Debrisoquine is a drug used for treating hypertension, and a wide variation has been observed in the hypotensive response. A clinical consequence of slow metabolism is the great sensitivity to the anti-hypertensive effects of debrisoquine (Idle 
CYP2E1 polymorphism in selected cancer sites (literature review).

\begin{tabular}{|c|c|c|c|c|c|}
\hline Authors & $\begin{array}{l}\text { Gene or } \\
\text { combined genes }\end{array}$ & Polymorphism & $\begin{array}{l}\text { Country/State/ } \\
\text { ethnic group }\end{array}$ & Cancer site & Results \\
\hline El-Zein et al. (1997) & CYP2E1 & RFLP-Rsa I & USA & Lung & $\mathrm{OR}=2.5(0.32-54)$ \\
\hline Lin et al. (1998) & CYP2E1 & RFLP-Rsa I & China & Esophagus & $\mathrm{OR}=4.8(1.8-12.4)$ \\
\hline Hung et al. (1997) & CYP2E1 & RFLP-Rsa I & Taiwan & Oral & $\begin{array}{l}\text { CYP2E1 }(c 1 / c 2 \text { and } c 2 / c 2) \\
\text { OR }=4.7(1.1-20.2)\end{array}$ \\
\hline Hirvonen et al. (1993) & CYP2E1 & RFLP-Dra I & Finland & Lung & NS (OR not given) \\
\hline Tan et al. (2000) & CYP2E1 & RFLP-Rsa I & China & Esophagus & $\begin{array}{l}\text { CYP2E1 (c1c1); OR = } 3.2(2.5-4.1) \\
\text { CYP2E1 }(c 1 c 1) \text { and GSTM1 00; } \\
\text { OR = 8.5 (3.7-19.9) }\end{array}$ \\
\hline Sugimura et al. (1995) & CYP2E1 & RFLP-Rsa I & Brazil & Lung & NS (OR not given) \\
\hline
\end{tabular}

NS = Not significant; OR= Odds ratio; RFLP = Restriction fragment length polymorphism .

et al., 1978). Meanwhile, although extensive metabolizers display less risk of the effects of overdoses from debrisoquine and related drugs, they show an increased risk (20 to 40 -fold) of developing cancer of the liver, gastrointestinal tract, and lung as compared to slow metabolizers (Nebert \& González, 1987).

Most individuals (80-90\%) have at least one wild allele (CYP2D6*1) for the CYP2D6 gene and are classified functionally as extensive metabolizers. There are two other groups of individuals: one with intermediate metabolic activity, known as intermediate metabolizers, and the other with ultra-rapid activity, known as ultra-rapid metabolizers. The first phenotype is attributed to a mutation in the wild allele (CYP2D6*1) and the second to an amplification of either the wild allele or an active mutant allele. Finally, there is a small group (5$10 \%$ of Caucasians, $2 \%$ of African Americans, and $1 \%$ of Orientals) who are poor metabolizers and identified by loss of gene function and absence of protein (Pavanello \& Clonfero, 2000).

An updated review of this complex polymorphism is provided by Sachse et al. (1997). According to these authors, different alleles for the CYP2D6 gene consist mainly of point mutations, conversions, gene duplications, and complete gene deletion. Some 15 alleles have been recorded and associated with low activity (CYP2D6*2, *9, *10) and with its absence (CYP2D6*3, *4, *5, *6, *7, *8, *11, *12, *13, *14, $* 15, * 16)$. The combination of all these alleles provides a wide range of possible phenotypes in relation to CYP2D6 activity. Given the nature of the substances metabolized by these enzymes, this polymorphism is used principally to identify poor metabolizers with anomalous responses to given drugs. In ultra-rapid metabolizers, the usual doses of given drugs fail to produce the desired pharmacological effect. Determination of CYP2D6 expression serves to detect therapeutic problems due to metabolism and can contribute to individualization of the dose regimen, reaching optimum drug therapeutic levels and reducing both cost and possible adverse effects (Chen et al., 1996).

\section{- CYP2D6 and cancer susceptibility}

Some studies on the association between the CYP2D6 gene and cancer are shown in Table 3. An association was observed between this gene and lung cancer (Caporaso et al., 1989, 1990; Roots et al., 1988) and oral cancer (Worrall et al., 1998). Increased CYP2D6 activity (EM phenotype) has been related to some malignant processes, like bladder cancer (Anwar et al., 1996). The data suggest that the increased metabolism of one or more agents in the diet or other environmental agents, mediated by CYP2D6, forms reactive intermediaries that influence the initiation or promotion of cancer in various tissues (Nebert, 1997). Meanwhile, reduced CYP2D6 activity (PM phenotype) has been related to greater risk of Parkinson's disease (Smith et al. 1992), leukemia (Roddam et al., 2000), and oral cancer (Worrall et al., 1998). The distinction is not clear between the EM and PM phenotypes and susceptibility to cancer. This could be explained by the fact that PM individuals, much less exposed than EMs to the metabolites of carcinogenic-genotoxic drugs, must be exposed longer to the toxic effects of 
CYP2D6 polymorphism in selected cancer sites (literature review).

\begin{tabular}{|c|c|c|c|c|c|}
\hline Authors & $\begin{array}{l}\text { Gene or } \\
\text { combined genes }\end{array}$ & Polymorphism & $\begin{array}{l}\text { Country/State/ } \\
\text { ethnic group }\end{array}$ & Cancer site & Results \\
\hline Roddam et al. (2000) & CYP2D6 & CYP2D6-PM & UK (Caucasians) & $\begin{array}{l}\text { Acute } \\
\text { lymphoblastic } \\
\text { leukaemia (ALL) }\end{array}$ & $\mathrm{OR}=1.69(1.17-2.43)$ \\
\hline Caporaso et al. (1990) & CYP2D6 & CYP2D6-EM & $\begin{array}{l}\text { USA (Caucasians } \\
\text { and African } \\
\text { Americans) }\end{array}$ & Lung & $\mathrm{OR}=6.1 ;(2.2-17.1)$ \\
\hline Smith et al. (1992) & CYP2D6 & RFLP-Hpa II & UK (Caucasians) & $\begin{array}{l}\text { Parkinson's } \\
\text { disease }\end{array}$ & $\mathrm{OR}=2.54(1.51-4.28)$ \\
\hline $\begin{array}{l}\text { Elexpuru-Camiruaga } \\
\text { et al. (1995) }\end{array}$ & CYP2D6 & CYP2D6-PM & UK (Caucasians) & $\begin{array}{l}\text { Astrocytoma } \\
\text { and meningioma }\end{array}$ & $\begin{array}{l}O R=4.17(1.57-11.09)-\text { astrocytoma } \\
O R=4.90(1.39-17.26)-\text { meningioma }\end{array}$ \\
\hline Worral et al. (1998) & CYP2D6 & CYP2D6-PM & UK (Caucasians) & Oral SCC & $\mathrm{OR}=3.2(1.6-6.5)$ \\
\hline Anwar et al. (1996) & GSTM1, CYP2D6 & $\begin{array}{l}\text { CYP2D6-EM, } \\
\text { GSTM1 } 00\end{array}$ & Egypt & Bladder & $\begin{array}{l}\text { GSTM1 } 00 \text { and CYP2D6 (EM); } \\
\text { OR }=6.97(1.6-30.6)\end{array}$ \\
\hline
\end{tabular}

$\mathrm{OR}=$ Odds ratio; $\mathrm{EM}=$ Extensive metabolizer $; \mathrm{PM}=$ Poor metabolizer .

non-metabolized drugs and numerous other factors still not identified (Taninghera et al., 1999). It is known that the toxic effects can contribute to carcinogenesis, for example, through a necrogenic response followed by compensatory increased cell division (Butterworth et al., 1992; Preston-Martin et al., 1990).

Patients with lung cancer have shown a greater frequency of genotype EM. This association is supported by the discovery that CYP2D6 can activate nitrosamine 4-(methylnitrosamino)-1-(3-piridyl)-1-butanone, specific to tobacco for reactive metabolites (Crespi et al, 1991). Kato et al. (1995) observed that the levels of DNA adducts in the lung were increased as a function of CYP2D6 activity, a result consistent with activation of tobacco mediated by this enzyme.

Finally, Elexpuru-Camiruaga et al. (1995), using logistic regression analysis, observed that both the GSTT1 null genotype and PM genotype for CYP2D6 were significant risk factors for astrocytoma (odds ratio $=2.67 ; 95 \%$ $\mathrm{CI}=1.53-4.65 ;$ and odds ratio $=4.17 ; 95 \% \mathrm{CI}=$ 1.57-11.09, respectively) and meningioma (odds ratio $=4.52 ; 95 \% \mathrm{CI}=2.18-9.34$; and odds ratio $=4.90 ; 95 \% \mathrm{CI}=1.39-17.26 ; \mathrm{p}=0.0132$, respectively) when corrected for other variables. These results suggest that polymorphisms in the XME coding loci influence susceptibility to astrocytoma and meningioma, possibly by determination of the efficiency of detoxification of environmental carcinogens.

\section{Genes for glutathione S-transferase (GST)}

The glutathione S-transferases (GSTs) constitute a super-family of isozymes of a complex multigenic nature, widely distributed in the animal kingdom (Mannervik, 1985). Their primary function is detoxification, mediating the conjugation of a large number of electrophilic compounds with reduced glutathione (GSH), in a typical phase II metabolic reaction (Pickett et al., 1989). These conjugation reactions facilitate the excretion of many xenobiotics, including carcinogens, toxins, and drugs in the form of mercapturic acids.

Different GST isozymes have been identified in human populations, some with tissuespecific expression (Board, 1981; Laisney et al., 1984; Suzuki et al., 1987). They are classified according to their physical, immunological, and structural properties and specificity in relation to the substrates and are determined by various gene loci, many of which already identified. In mammals they are expressed at a higher level in the liver, constituting more than $4 \%$ of total soluble protein (Eaton \& Bammler, 1999), and at least seven distinct families of soluble GSTs have been identified: alpha $(\alpha)$, mu $(\mu)$, pi $(\pi)$, sigma $(\sigma)$, theta $(\theta)$, kappa $(\kappa)$, and zeta $(\zeta)$ (Landi, 2000). 


\section{GSTM1}

In the mu class, at least five distinct genes for GSTM have been cloned and sequenced: GSTM1, GSTM2, GSTM3, GSTM4, and GSTM5 (Campbell et al., 1990; Gough et al., 1994; Takahashi et al., 1993; Taylor et al., 1990; Vorachek et al.,1991; Zhong et al., 1993a). All these five genes were mapped in the short arm of chromosome 1, while the GSTM1 gene is located in region 1p13 (Pearson et al., 1993; Zhong et al., 1992).

The GSTM1 gene is polymorphic and represented by a non-functional null allele, GSTM $1 * 0$ (Seidegard et al., 1988) and by two other active alleles, GSTM1*A and GSTM1*B, which differ by a single base pair in exon 7 , introducing a restriction site for Hae II in the gene sequence (Fryer et al., 1993). The product of this gene catalyzes the detoxification of alkyl and polycyclic aromatic hydrocarbons that are intermediary forms of many carcinogens. It is also capable of reducing some superoxides and the products of oxidative stress, such as the DNA hydroperoxides (Smith et al., 1995). The GSTM1 null allele appears to be the result of an unequal "crossing-over" between two highly identical 4.2-kb repeat regions flanking the GSTM1 gene, resulting in a $15-\mathrm{kb}$ deletion that includes the entire GSTM1 gene (Xu et al., 1998). The proportion of homozygous GSTM1 0/0 individuals is quite variable in different racial groups, ranging from 20 to $60 \%$ (Board et al., 1990).

Interest in GSTM1 has been stimulated by studies indicating that homozygosity for GSTM1*0 is associated with increased risk of various diseases, including chronic bronchitis (Baranova et al., 1997), arteriosclerosis (Pessah-Rasmussen et al., 1992), and various types of cancer: lung (Seidegard et al., 1986, 1990), adenocarcinoma (Strange et al., 1991), and colorectal (Zhong et al., 1993b). These studies are based on the hypothesis that the presence or absence of GSTM1 is a determinant factor in susceptibility to the disease. GSTM1 deficiency may be a risk factor for cancer, causing greater sensitivity to given chemical carcinogens (Strange et al., 1991; Van Poppel et al., 1992).

\section{GSTM3}

GSTM3 is also a mu class GST, located in chromosome 1p13.3 (Gough et al., 1994; Pearson et al., 1993). This polymorphism was identified by Inskip et al. (1995), who used PCR with specific oligonucleotides for exons 6 and 7 to demon- strate different alleles in the GSTM3 gene. Sequencing showed a mutant allele GSTM3*B with a 3-bp deletion in intron 6 . These authors also observed that the GSTM3*B allele was significantly associated with the GSTM1*A allele, displaying a very close linkage to the locus for the GSTM1 gene. Two distinct interactions were observed between GSTM1 and GSTM3. First, Nakajima et al. (1995) showed that GSTM1 null individuals expressed lower levels of GSTM3 and possibly of GSTM2. No mechanism was proposed for this effect. Meanwhile, data from Inskip et al. (1995) showed that individuals expressing GSTM1, GSTM1 A, and GSTM1 B could display different susceptibilities due to linkage with GSTM3. This would explain results showing a lower frequency of GSTM1*B in the cancer patient group (Heagerty et al., 1994). The mechanism is still not clear, since GSTM1*A and GSTM $1 * \mathrm{~B}$ have similar structural and catalytic properties. Identification of the GSTM3 polymorphism linked to GSTM1*A suggests that GSTM1 A confers greater susceptibility due to its association with GSTM3*B. Thus, GSTM1 A individuals must demonstrate reduced expression of GSTM3 due to the YY1 negative transcription factor. This factor appears to regulate the expression of intragenic sequences in various genes, including $c$-myc (Hariharan et al., 1991). These data suggest that in the determination of the role of GSTM1 in cancer susceptibility it may also be necessary to consider complex interactions among the various members of this family (Inskip et al., 1995).

\section{GSTP1}

A genetic polymorphism, GSTP1, has been described in the $p i$ class of glutathione S-transferase. The GSTP1 gene is located on chromosome 11q13 (Board et al., 1989; Moscow et al., 1988) and the enzyme is expressed primarily in tissues like placenta, spleen, heart, and lung (Kelley et al., 1994).

The GSTP1 polymorphisms were first reported by Board et al. (1990). Four GSTP1 alleles have been described: the wild-type GSTP $1 * A$ allele and three other variant alleles called GSTP1*B, GSTP1*C, and GSTP1*D (Ali-Osman et al., 1997; Watson et al., 1998). These different alleles result from the combination of two single nucleotide polymorphisms within the GSTP1 gene, one of which resulting in a change at codon 105 (Ile/Val), and the other at codon 114 (Ala/Val). GSTP1*A is the most common haplotype and has Ile at codon 105 and Ala at codon 114 . The second, GSTP $1 * \mathrm{~B}$, has Val at 
codon 105 and Ala at codon 114 . GSTP $1{ }^{*} \mathrm{C}$ has Val at both, codon 105 and 114. Finally, GSTP1*D is a rare allele which contains the wild-type codon 105 sequence (Ile) and Val at codon 114 (Ali-Osman et al., 1997; Watson et al., 1998).

Studies have demonstrated that the coding region polymorphisms and different GSTP1 isoforms exhibit differences in substrate specificity and thermal stability properties, possibly leading to functional alteration, conferring different catalytic activities (Ali-Osman et al., 1997; Harries et al., 1997; Zimniak et al., 1994). Enzymes with 105Val alleles have a seven-fold greater catalytic efficiency for polycyclic aromatic hydrocarbon diol epoxides, but threefold lower efficiency for 1-chloro-2,4-dinitrobenzene when compared with GSTP1*A allele (Ali-Osman et al., 1997; Harries et al., 1997; Sundberg et al., 1998; Watson et al., 1998; Zimniak et al., 1994).

Increased expression of the GSTP1 gene has been associated with malignant transformation, resistance to anti-tumoral drugs, and decreased survival (Commandeur et al., 1995; Morrow \& Cowan, 1990; Tew, 1994; Tsuchida \& Sato, 1992). In many human tumors and preneoplastic lesions, the GSTP1 protein is overexpressed, even when the protein is absent or present at very low levels in corresponding normal tissue. Individuals with the 105Val allele have a higher risk of developing lung cancer than individuals with the 105Ile allele (Ryberg et al., 1997). A four-fold greater frequency of the GSTP $1 * \mathrm{C}$ variant in malignant gliomas was found when compared to normal tissue (Ali-Osman et al., 1997). The authors provide conclusive molecular evidence that the polymorphism in the human GSTP1 gene results in active proteins that are functionally different and may facilitate studies on the importance of these genes in xenobiotic metabolism, cancer, and other human disease (Ali-Osman et al., 1997).

\section{GSTT1}

Two genes have been identified in the theta class: GSTT1 and GSTT2, located in chromosome 22, in the same region, 22q11.2 (Webb et al., 1996). In humans, GSTT1 is polymorphic and represented by two alleles: a functional or wild allele (GSTT ${ }^{*} 1$ ) and a non-functional or null allele $\left(\mathrm{GSTT} 1^{*} 0\right)$. Studies have demonstrated that the GSTT $1 * 0$ allele corresponds to a total or partial deletion of the gene, causing a deficiency in enzymatic activity (Hallier et al., 1993; Pemble et al., 1994). Two phenotypes are possible: "GSTT1 null", the homozygote for the deleted allele, and "GSTT1-positive", the phenotype with at least one copy of the gene. The frequency of the GSTT1 null genotype in Caucasian populations is approximately $20 \%$ (Pemble et al., 1994), while this frequency is different in other ethnic groups: $64.4 \%$ in Chinese and $60.2 \%$ in Koreans (Nelson et al., 1995); 20-24\% in African Americans (Abdel-Rahman et al., 1996; Chen et al., 1996; Nelson et al., 1995). GSTT1 appears to be the main enzyme involved in the biotransformation of various low molecular weight toxins, like ethylene oxide, mono- and dihalomethanes, and other substrates, many of which are known or suspected carcinogens. It is difficult to predict the biological consequences of the null genotype, since this enzyme has the properties of detoxifying and activating many environmental pollutants. An increase was observed in the rate of sister chromatid exchanges (SCE) induced in vitro by 1,3-epoxy-3-butene in lymphocyte cultures of individuals classified as GSTT1 null (Bernardini et al., 1998). Chromosomal aberrations were significantly greater in GSTT1 null workers exposed to 1,3-butadiene (Sorsa et al., 1996). GSTT1 null smokers had significantly more chromosomal aberrations than smokers expressing the gene (El-Zein et al., 1997). Methylbromide, a neurotoxic and mutagenic compound, is metabolized by GSTT1. Of two individuals accidentally exposed to this compound, the GSTT1-positive individual showed severe signs of neurotoxicity, suggesting that neurotoxic metabolites are formed by GSTT1, while the individual not expressing GSTT1 had higher levels of S-methylcysteine adducts in blood proteins, which is indicative of increased levels of mutagenic metabolites (Garnier et al., 1996). The null phenotype also appears to lead to greater susceptibility to tobacco- and alcohol-related types of cancer (Brockmöller et al., 1996; Hayes \& Pulford, 1995).

\section{GST and susceptibility to cancer}

Most of the studies on the role of GST polymorphisms in the development of cancer have focused on GSTM1, with fewer (but more recent) studies on GSTT1, GSTM3, and GSTP1. In Table 4, some of them are shown.

In relation to lung cancer, for example, Seidegard et al. (1986) showed that smokers deficient in GSTM1, that is, homozygotes for the null allele, showed increased risk for this type of cancer. Meanwhile, the presence of the whole gene appeared to protect against chemicallyinduced cytogenetic damage (Scarpato et al., 1997; Van Poppel et al., 1992) and DNA adducts 
GSTM1, GSTM3, GSTT1, and GSTP1 polymorphism of in selected cancer sites (literature review).

\begin{tabular}{|c|c|c|c|c|c|}
\hline Authors & $\begin{array}{l}\text { Gene or } \\
\text { combined genes }\end{array}$ & Polymorphism & $\begin{array}{l}\text { Country/State/ } \\
\text { ethnic group }\end{array}$ & Cancer site & Results \\
\hline Ryberg et al. (1997) & GSTP1 & GSTP1 GG & Norway & Lung & $\begin{array}{l}\text { GSTP1 (OR = } 1.7(1.13-2.57 ; \mathrm{p}=0.011) \text {, } \\
\text { all patients } \\
\text { GSTP1 (G-) vs AA (OR=2.5(1.41-4.42) } \\
\text { in SCC } \\
\text { GSTP1 (G-) and GSTM1 00 vs other } \\
\text { combinations (OR = } 1.96(1.26-3.06), \\
\text { all patients } \\
\text { GSTP1 GG genotype patients had a } \\
\text { significantly higher adduct level }\end{array}$ \\
\hline To-Figueras et al. (1997) & GSTM1 & GSTM1-00 & $\begin{array}{l}\text { Northwestern } \\
\text { Mediterranean } \\
\text { Caucasians }\end{array}$ & Lung & $\mathrm{OR}=1.40(0.74-2.61)$ \\
\hline Nyberg et al. (1998) & GSTM1 & GSTM1-00 & Sweden & Lung & $\mathrm{OR}=0.8(0.5-1.2)$ \\
\hline Brockmoller et al. (1996) & GSTM1 & $\begin{array}{l}\text { GSTM1-00, } \\
\text { GSTM1-A- }\end{array}$ & $\begin{array}{l}\text { Germany } \\
\text { (Caucasians) }\end{array}$ & Bladder & $\begin{array}{l}\text { GSTM1 non } A ; \text { OR }=1.9(1.2-3.2) \\
\text { GSTM1 00; OR }=1.6(1.2-2.2)\end{array}$ \\
\hline Janke et al. (1996) & $\begin{array}{l}\text { GSTM1 } \\
\text { GSTM3 } \\
\text { GSTT1 }\end{array}$ & $\begin{array}{l}\text { GSTM1 AB } \\
\text { GSTM3 BB } \\
\text { GSTT1-null }\end{array}$ & $\begin{array}{l}\text { Germany } \\
\text { (Caucasians) }\end{array}$ & Larynx & $\begin{array}{l}\operatorname{GSTM1}\left(\chi^{2}=4.22 ; p=0.04\right) \\
\operatorname{GSTM} 3\left(\chi^{2}=5.97 ; p=0.015\right) \\
\operatorname{GSTT1}\left(\chi^{2}=3.90 ; p=0.064\right)\end{array}$ \\
\hline Heagerty et al. (1994) & GSTM1 & GSTM1 AB & UK & Skin & $\begin{array}{l}\text { GSTM1 A/B was reduced in frequency } \\
(p<0.05)\end{array}$ \\
\hline $\begin{array}{l}\text { Jourenkova-Mironova } \\
\text { et al. (1998) }\end{array}$ & $\begin{array}{l}\text { GSTM3, GSTM1, } \\
\text { GSTP1 }\end{array}$ & $\begin{array}{l}\text { GSTM3 AA, } \\
\text { GSTM1 00, } \\
\text { GSTP1 G- }\end{array}$ & $\begin{array}{l}\text { France } \\
\text { (Caucasians) }\end{array}$ & Lung & $\begin{array}{l}\text { GSTM3 AA and GSTP1 (G-); OR = } 2.9 \\
(0.7-12.1) \\
\text { GSTM3 AA and GSTP1 (G-) and } \\
\text { GSTM1 00; OR = } 2.7(1.2-6.0) \text { in heavy } \\
\text { smokers }\end{array}$ \\
\hline Yengi et al. (1996) & GSTM3 & GSTM3 AA & UK (Caucasians) & $\begin{array}{l}\text { Cutaneous } \\
\text { basal cell } \\
\text { carcinoma }\end{array}$ & NS (OR not given) \\
\hline Hand et al. (1996) & GSTM3 & GSTM3 AA & $\begin{array}{l}\text { Europe } \\
\text { (Caucasians) }\end{array}$ & Astrocytoma & NS (OR not given) \\
\hline Harries et al. (1997) & GSTP1 & codon 105 & UK & $\begin{array}{l}\text { Lung, bladder, } \\
\text { and testicular }\end{array}$ & $\begin{array}{l}\text { Lung cancer; NS (OR not given) } \\
\text { Bladder cancer; OR = } 3.6(1.4-9.2) \\
\text { Testicular cancer; OR = } 3.3(1.5-7.7)\end{array}$ \\
\hline Harris et al. (1998) & GSTP1 & $\begin{array}{l}\text { codons } 105 \\
\text { and } 114\end{array}$ & Australia & $\begin{array}{l}\text { Colorectal } \\
\text { and lung }\end{array}$ & NS (OR not given) \\
\hline $\begin{array}{l}\text { Jourenkova-Mironova } \\
\text { et al. (1999) }\end{array}$ & $\begin{array}{l}\text { GSTM3 and } \\
\text { GSTM1 }\end{array}$ & GSTM3 AA & $\begin{array}{l}\text { France } \\
\text { (Caucasians) }\end{array}$ & Larynx & $\begin{array}{l}\text { GSTM3 }(\mathrm{AB} \text { or } \mathrm{BB}) ; \mathrm{OR}=2.0(1.1-3.4) \\
\mathrm{GSTM} 3(\mathrm{AB} \text { or } \mathrm{BB}) \text { and GSTM1 00; } \\
\mathrm{OR}=4.0(1.6-10.1)\end{array}$ \\
\hline Jourenkova et al. (1998) & $\begin{array}{l}\text { GSTM1 and } \\
\text { GSTT1 }\end{array}$ & $\begin{array}{l}\text { GSTM1 } 00 \\
\text { GSTT1-null }\end{array}$ & $\begin{array}{l}\text { French } \\
\text { Caucasians }\end{array}$ & Larynx & $\begin{array}{l}\text { GSTM1; OR = } 1.6(1.0-2.8) \\
\text { GSTT1; OR = } 1.4(0.7-2.9) \\
\text { (GSTM } 00 \text { and GSTT1-null) } \\
\text { vs (GSTM } 00 \text { or GSTT1 null); } \\
\text { OR }=2.0(0.8-5.2) \\
\text { (GSTM } 00 \text { and GSTT1 null) } \\
\text { vs (GSTM }(+) \text { and GSTT1 (+)); } \\
\text { OR }=2.7(1.0-7.4)\end{array}$ \\
\hline Park et al. (1997) & GSTM1 & GSTM1-00 & USA (Caucasians) & Oral & $\mathrm{OR}=1.0(0.6-1.7)$ \\
\hline Mathias et al. (1998) & GSTM1 & GSTM1 AB & $\begin{array}{l}\text { Germany } \\
\text { (Caucasians) }\end{array}$ & $\begin{array}{l}\text { Upper } \\
\text { aerodigestive } \\
\text { tract }\end{array}$ & $\mathrm{OR}=0.1(0.0-0.7)$ \\
\hline
\end{tabular}

(to be continued on next page) 
Table 4 (continued from previous page)

\begin{tabular}{|c|c|c|c|c|c|}
\hline Authors & $\begin{array}{l}\text { Gene or } \\
\text { combined genes }\end{array}$ & Polymorphism & $\begin{array}{l}\text { Country/State/ } \\
\text { ethnic group }\end{array}$ & Cancer site & Results \\
\hline Heagerty et al. (1996) & $\begin{array}{l}\text { GSTM1, } \\
\text { CYP2D6 (EM) }\end{array}$ & GSTM1 AB & UK & Skin & $\begin{array}{l}\text { GSTM1 A/B }\left(\chi^{2}=4.52, d f=1,\right. \\
p=0.048)^{\star} \\
\text { GSTM1 A/B and CYP2D6 EM, } \\
\left(\chi^{2}=8.75, d f=3, p=0.033\right)^{\star} \\
\text { GSTM1 } 00 \text { and skin type } 1\left(\chi^{2}=6.87\right. \\
d f=1, p=0.009) \text { single vs multiple BCC }\end{array}$ \\
\hline Helzsouer et al. (1998) & GSTM1 & GSTM1-00 & USA & Breast & $\begin{array}{l}\text { GSTM1; OR = } 2.50(1.34-4.65)- \\
\text { postmenopausal women } \\
\text { GSTM1 } 00 \text { and GSTT1 null and GSTP1 } \\
\text { (val/-); OR = } 3.77(1.10-12.88) \text {, in } \\
\text { breast cancer }\end{array}$ \\
\hline Maugard et al. (1998) & GSTM1 & GSTM1-00 & $\begin{array}{l}\text { France } \\
\text { (Caucasians) }\end{array}$ & Breast & $\begin{array}{l}\operatorname{GSTM} 1\left(\chi^{2}=6.26 ; p=0.009\right)- \\
\text { patients } \geq 55 \text { years }\end{array}$ \\
\hline Charrier et al. (1999) & GSTM1 & GSTM1-00 & $\begin{array}{l}\text { France } \\
\text { (Caucasians) }\end{array}$ & Breast & $\mathrm{OR}=1.99(1.19-3.32)$ \\
\hline Ambrosone et al. (1995) & GSTM1 & GSTM1-00 & USA (Caucasians) & Breast & $\begin{array}{l}\text { OR }=2.44(0.89-6.64) \text { - youngest } \\
\text { postmenopausal women }\end{array}$ \\
\hline Park et al. (2000) & $\begin{array}{l}\text { GSTM1 and } \\
\text { GSTM3 }\end{array}$ & GSTM1-00 & $\begin{array}{l}\text { USA (African } \\
\text { Americans and } \\
\text { Caucasians) }\end{array}$ & Oral & $\begin{array}{l}\text { GSTM } 1 ; \text { OR }=3.1(1.1-8.5) \\
\text { GSTM } 1(+) \text { and GSTM3(A-); OR }=2.2 \\
(0.82-6.0) \\
\text { GSTM } 1(00) \text { and GSTM3(BB); OR = } 4.3 \\
(1.1-16) \\
\text { GSTM1(00) and GSTM3(A-); OR = } 6.6 \\
(1.2-38) \text { (Only African Americans) }\end{array}$ \\
\hline Curran et al. (2000) & GSTM1 e GSTT1 & & Australia & Breast & NS (OR not given) \\
\hline Lan et al. (2000) & GSTM1 & GSTM1-00 & China & Lung & $\mathrm{OR}=2.3(1.3-4.2)$ \\
\hline Kempkes et al. (1996) & GSTM1 & GSTM1-00 & Germany & Bladder & $\mathrm{OR}=1.81(1.10-2.98)$ \\
\hline Anwar et al. (1996) & GSTM1 & GSTM1-00 & Egypt & Bladder & GSTM1; OR = $6.97(1.6-30.6)$ \\
\hline Deakin et al. (1996) & GSTT1 & GSTT1 null & UK & Colorectal & GSTT1; OR = $1.88(1.28-2.77)$ \\
\hline Mitrunen et al. (2001) & $\begin{array}{l}\text { GSTM1, GSTP1, } \\
\text { GSTM3 and } \\
\text { GSTT1 }\end{array}$ & $\begin{array}{l}\text { GSTM3 BB, GSTP1 } \\
\text { ile/ile, GSTM1-00 } \\
\text { and GSTT1-null }\end{array}$ & Finland & Breast & $\begin{array}{l}\text { GSTM1; OR }=1.49(1.03-2.15) \\
\text { postmenopausal women } \\
\text { GSTM3(A-) and GSTP1 ile/ile; } \\
\text { OR }=2.07(1.02-4.18)^{\star \star} \\
\text { GSTM3(B-) and GSTP1 ile/ile and } \\
\text { GSTT1 null; OR }=9.93(1.10-90.0) * \star\end{array}$ \\
\hline Van Lieshout et al. (1999) & GSTP1 & Codon 105 & $\begin{array}{l}\text { Netherlands } \\
\text { (Caucasians) }\end{array}$ & Esophagus & $\begin{array}{l}\left(\chi^{2}=25.14 ; p=0.0001\right)-\text { in Barrett's } \\
\text { esophagus } \\
\left(\chi^{2}=10.53 ; p=0.005\right)-\text { in } \\
\text { adenocarcinoma }\end{array}$ \\
\hline Nair et al. (1999) & GSTM1 e GSTT1 & $\begin{array}{l}\text { GSTM1-00 and } \\
\text { GSTT1-null }\end{array}$ & India & Oral & $\begin{array}{l}\text { GSTM1; OR = } 22.0(10.0-47.0) \\
\text { GSTT1; OR = } 11.0(5.0-22.0)\end{array}$ \\
\hline Chen et al. (1997) & GSTM1 e GSTT1 & $\begin{array}{l}\text { GSTM1 } 00 \text { and } \\
\text { GSTT1 null }\end{array}$ & USA & $\begin{array}{l}\text { Acute } \\
\text { lymphoblastic } \\
\text { leukemia (ALL) }\end{array}$ & $\begin{array}{l}\text { GSTM1 } 00 \text { and GSTT1 null genotype } \\
\text { among patients vs normal control; } \\
23.5 \% \text { vs } 3.9 \%, p=.0005 \text { (Only } \\
\text { African American patients with ALL) }\end{array}$ \\
\hline
\end{tabular}

NS = Not significant OR= Odds ratio; $d f=$ Degree of freedom; SCC = Squamous cell carcinoma;

$\mathrm{BCC}=$ Basal cell carcinoma; ${ }^{*}$ controls vs multiple $\mathrm{BCC} ;{ }^{* \star}$ premenopausal women 
in the lung (Liu et al., 1991; Shields et al., 1993). Ryberg et al. (1997) showed that the level of DNA adducts in the lungs of male smokers was influenced more by GSTP1 than by GSTM1. According to these authors, smokers with at least one mutant allele for GSTP1 showed significantly higher levels of DNA adducts than controls, while the GSTM1 null genotype did not show higher levels. When they combined the two polymorphisms GSTM1 and GSTP1 they observed that patients with the GSTM1 null genotype and the GSTP1 genotype with at least one mutant allele had significantly higher levels of adducts than other combinations (Ryberg et al., 1997). This fact tends to support the relationship between genotoxicity and GSTP1 polymorphism (Kristensen et al., 1998).

To-Figueras et al. (1997) did not observe a significantly greater frequency of the GSTM1 null genotype in lung cancer cases in a Caucasian population, which agrees with data from Nyberg et al. (1998). Meanwhile, the frequency of the other genotypes GSTM1 A, GSTM1 B, and GSTM1 A/B did not differ between cases and controls (To-Figueras et al., 1997), unlike the results of other studies in tumors of the bladder, larynx, and skin, in which a protective role was proposed for GSTM1*A (Brockmöller et al., 1994, 1996) and GSTM1*A/GSTM1*B (Heagerty et al., 1994; Jahnke et al., 1996).

Recently, Jourenkova-Mironova et al. (1998) studied the influence of four GST polymorphisms (GSTM1, GSTT1, GSTM3, and GSTP1) on lung cancer susceptibility. The results showed that when studied separately, GSTM3 and GSTP1 did not contribute significantly to the risk of lung cancer. The GSTM3 results are in agreement with those observed in patients with basal cell carcinoma (Yengi et al., 1996) and astrocytoma (Hand et al., 1996). As for GSTP1, the findings are consistent with those of two other recent studies (Harries et al., 1997; Harris et al., 1998), but not with those of a third study showing a 1.7-fold risk (95\% CI: 1.132.57) of lung cancer (Ryberg et al., 1997). When Jourenkova-Mironova et al. (1998) analyzed the combinations of the four polymorphisms, they noted that the combination of genotypes GSTM3 AA and GSTP1 (AG or GG) and GSTM1 null conferred an increased (although statistically non-significant) risk of lung cancer (OR = 2.9, 95\% CI: 0.7-12.1). Later, Jourenkova-Mironova et al. (1999), studying cancer of the larynx, observed a significant increase in risk related to genotype GSTM3 AB or $\mathrm{BB},(\mathrm{OR}=2.0 ; 95 \%$ CI: 1.1-3.4) and the combination of this genotype with GSTM1-null conferring a four-fold risk (95\% CI: 1.6-10.1).
Various authors have described family clustering in oral cancer (Foulkes et al., 1995), and the proposed explanation involves gene polymorphisms for drug-metabolizing enzymes. Jourenkova et al. (1998) studied the effects of genotypes GSTM1 and GSTT1 on the risk of cancer of the larynx and observed an increased risk related to the GSTM1 null genotype and greater (although not significant) risk for GSTT1 null. Individuals lacking both genes GSTM1 and GSTT1 had a two-fold risk, although not significant, as compared to those with at least one of the genes, and a three-fold risk as compared to those with both genes. In addition, a statistically significant interaction was observed between the GSTM1 genotypes and levels of tobacco consumption $(p<0.05)$. However, Park et al. (1997) failed to find an association between the GSTM1 null allele and oral cancer. Meanwhile, Matthias et al. (1998), studying cancer of the upper aerodigestive tract (oral, laryngeal, and pharyngeal squamous cell carcinoma), did not observe differences in the frequency of the GSTT1-null genotype between cases and controls, but did observe that the frequency of genotype GSTM1 A/B was significantly lower in patients with oral, laryngeal, and pharyngeal squamous cell carcinoma, suggesting a protective effect, while genotype GSTM3 A/A moderately increased the risk (Matthias et al., 1998). Previously, Heagerty et al. (1996) had already observed that genotype GSTM1 A/B was associated with reduced risk of multiple cutaneous basal cell carcinomas. The influence of GSTM1 A/B, but not of GSTM1 A or GSTM1 B (principally heterozygotes with GSTM1*0), suggests a dose-gene effect (Strange et al., 1998).

Recent epidemiological studies on GSTs and breast cancer have been inconsistent. Some studies suggest an association between the GSTM1 null genotype and breast cancer in postmenopausal women (Charrier et al., 1999; Helzlsouer et al., 1998; Maugard et al., 1998), but these results disagree with various other studies (Ambrosone et al., 1995, 1999; Kelsey \& Wiencke, 1998; Zhong et al., 1993b). More recently, Park et al. (2000) observed that the GSTM1 null genotype showed a statistically significant association with breast cancer, increasing the risk in premenopausal but not in postmenopausal women, while the GSTT1 null genotype showed similar risk levels in all the groups analyzed. When they combined these two genotypes, they observed that the presence of both null alleles significantly increased the risk of this cancer, especially in premenopausal women and those who consumed 
alcohol, suggesting a gene-environment interaction in individual susceptibility to breast cancer (Park et al., 2000). These results disagree with those of Curran et al. (2000), who failed to find any association between polymorphisms GSTM1, GSTP1, and GSTT1 and breast cancer in an Australian sample.

Other independent studies on various types of cancer have also shown this relationship between XMEs and lung cancer (Lan et al., 2000), bladder cancer (Anwar et al., 1996; Kempkes et al., 1996), colorectal cancer (Deakin et al., 1996), breast cancer (Mitrunen et al., 2001), esophageal cancer (Van Lieshout et al., 1999), oral cancer (Nair et al., 1999), and leukemia (Chen et al., 1997).

\section{Conclusions}

Prevention is crucial and effective for reducing cancer mortality. The fact that many cancers are caused by various forms of environmental and viral exposure suggests that such causes could be avoided through preventive measures. In addition, metabolism of carcinogens under genetic control as an important factor in modulating individual susceptibility to cancer is a plausible hypothesis. Information on susceptibility to cancer is valuable for identifying high-risk individuals, allowing for early diagnosis and reduction of risk exposure to carcinogens, some of them possibly acting as endocrine disruptors.

Recent knowledge on the basic genetics of metabolic variation has provided new possibil-

\section{Acknowledgments}

I wish to thank Ms. Christiane F. S. Marques and Dr. Sérgio Koifman for their critical reading of this paper. The research work was sponsored by Fundação Oswaldo Cruz (FIOCRUZ) and Fundação de Amparo à Pesquisa do Rio de Janeiro (FAPERJ). ities for the study of individual susceptibility to cancer induced by the environment. With the advent of techniques based on the polymerase chain reaction (PCR), it is now possible to identify the genotype of an individual with a series of enzymatic polymorphisms involved in the metabolism of xenobiotics, some of which are potent carcinogens. New molecular biology techniques have allowed for much more direct correlations between a particular genotype and the incidence of cancer and other chemicallyinduced diseases. Given the number of polymorphisms, the variability in the expression of XMEs, and the complexity of chemical exposure, determination of a single polymorphic enzyme may not be sufficient, and it appears to be necessary to establish a risk profile for each individual or sub-group. The conflictive results observed in the literature show the still present difficulty to evaluate this complex phenomenon. The number of genes responsible for determining risk is still not clear. Studies combining various XME genotypes from phases I and II of metabolism may be provide more information than the analysis of individual genes, since if genetic susceptibility is partially mediated by polymorphic variation, the risk associated with only one locus is probably small, due to the multiplicative interaction model probably at play. One of the futture challenges in molecular epidemiology maybe resides in the ability to evaluate different scenarios in which interactions among several genetic polymorphisms, and among gene/s and environmental carcinogens yield different susceptibility levels on cancer etiology.

\section{References}

ABDEL-RAHMAN, S. Z.; EL-ZEIN R. A.; ANWAR, W. A. \& AU, W. W., 1996. A multiplex PCR procedure for polymorphic analysis of GSTM1 and GSTT1 genes in population studies. Cancer Letters, 107:229-233.

ALI-OSMAN, F.; AKANDE, O.; ANTOUN, G.; MAO, J. X. \& BUOLAMWINI, J., 1997. Molecular cloning, characterization, and expression in Escherichia coli of full-length cDNAs of three human glutathione S-transferase Pi gene variants. Evidence for differential catalytic activity of the encoded proteins. Journal of Biological Chemistry, 272: 10004-10012.

AMBROSONE, C. B.; COLES, B. F; FREUDENHEIM, J. L. \& SHIELDS, P. G., 1999. Glutathione-S-transferase (GSTM1) genetic polymorphisms do not affect human breast cancer risk, regardless of dietary antioxidants. Journal of Nutrition, 129:565S$568 S$. 
AMBROSONE, C. B.; FREUDENHEIM, J. L.; GRAHAM, S.; MARSHALL, J. R.; VENA, J. E.; BRASURE, J. R.; LAUGHLIN, R.; NEMOTO, T.; MICHALEK, A. M.; HARRINGTON, A.; FORD, T. D. \& SHIELDS, P. G., 1995. Cytochrome P4501A1 and glutathione Stransferase (M1) genetic polymorphisms and postmenopausal breast cancer risk. Cancer Research, 55:3483-85.

ANWAR, W. A.; ABDEL-RAHMAN, S. Z.; EL-ZEIN, R. A.; MOSTAFA, H. M. \& AU, W. W. 1996. Genetic polymorphism of GSTM1, CYP2E1 and CYP2D6 in Egyptian bladder cancer patients. Carcinogenesis, 17:1923-1929.

AUTRUP, H., 2000. Genetic polymorphisms in human xenobiotic metabolizing enzymes as susceptibility factors in toxic response. Mutation Research, 464:65-76.

AYESH, R.; IDLE, J. R.; RITCHIE, J. C.; CROTHERS, M. J. \& HETZEL, M. R., 1984. Metabolic oxidation phenotypes as markers for susceptibility to lung cancer. Nature, 312:169-170.

BAILEY, R. L.; ROODI, N.; VERRIER, C. S.; YEE, C. J.; DUPONT, W. D. \& PARL, F. F., 1998. Breast cancer and CYP1A1, GSTM1, and GSTT1 polymorphisms: Evidence of a lack of association in Caucasians and African Americans. Cancer Research, 58:6570.

BARANOVA, H.; PERRIOT, J.; ALBUISSON, E.; IVASCHENKO, T.; BARANOV, V. S.; HEMERY, B.; MOURAIRE, P.; RIOL, N. \& MALET, P., 1997. Peculiarities of the GSTM1 0/0 genotype in French heavy smokers with various types of chronic bronchitis. Human Genetics, 99:822-826.

BERNARDINI, S.; HIRVÖNEN, A.; PELIN, K. \& NORPPA, H., 1998. Induction of sister chromatid exchange by 1,2-epoxy-3-butene in cultured human lymphocytes: Influence of GSTT1 genotype. Carcinogenesis, 19:377-380.

BERTILSSON, L., 1995. Geographical/interracial differences in polymorphic drug oxidation. Current state of knowledge of cytochromes P450 (CYP) 2D6 and 2C19. Clinical Pharmacokinet, 29:192209.

BOARD, P. G., 1981. Biochemical genetics of glutathione S-transferase in man. American Journal of Human Genetics, 33:36-43.

BOARD, P. G.; COGGAN, M.; JOHNSTON, P.; ROSS, V.; SUZUKI, T. \& WEBB, G., 1990. Genetic heterogeneity of the human glutathione transferases: A complex of gene families. Pharmacology and Therapy, 48:357-369.

BOARD, P. G.; WEBB, G. C. \& COGGAN, M., 1989. Isolation of a cDNA clone and localization of human glutathione S-transferase 2 genes to chromosome band $11 \mathrm{q} 13$ and 12q13-14. Annals of Human Genetics, 53:205-213.

BROCKMÖLLER, J.; CASCORBI, I.; KERB, R. \& ROOTS, I., 1996. Combined analysis of inherited polymorphism in arylamine $\mathrm{N}$-acetyltransferase 2 , glutathione S-transferases M1 and T1, microsomal epoxide hydrolase, and cytochrome P450 enzymes as modulators of bladder cancer risk. Cancer Research, 56:3915-3925.

BROCKMÖLLER, J.; KERB, R.; DRAKOULIS, N.; STAFFELDT, B. \& ROOTS, I., 1994. Glutathione Stransferase $\mathrm{M} 1$ and its variants A and B as host factors of bladder cancer susceptibility: A casecontrol study. Cancer Research, 54:4103-4111.

BUTTERWORTH, B. E.; POPP, J. A.; CONOLLY, R. B. \& GOLDSWORTHY, T. L., 1992. Chemically induced cell proliferation in carcinogenesis. In: Mechanisms of Carcinogenesis in Risk Identification (H. Vainio, P. Magee, D. B. McGregor \& A. J. McMichael, ed.), IARC Scientific Publication 116, pp. 279-305. Lyon: International Agency for Research on Cancer.

CAMPBELL, E.; TAKAHASHI, Y.; ABRAMOVITZ, M.; PERETZ, M. \& LISTOWSKY, I., 1990. A distinct human testis and brain mu-class glutathione Stransferase. Journal of Biological Chemistry, 265:9188-9193.

CAPORASO, N.; PICKLE, L. W.; BALE, S.; AYESH, R.; HETZEL, M. \& IDLE, J., 1989. The distribution of debrisoquine metabolic phenotypes and implications for the suggested association with lung cancer risk. Genetic Epidemiology, 6:517-524.

CAPORASO, N. E.; TUCKER, M. A.; HOOVER, R. N.; HAYES, R. B.; PICKLE, L. W.; ISSAW, H. J.; MUSCHIK, G. M.; GREEN-GALLO, L.; BUIVYS, D.; AISNER, S.; RESAU, J. H.; TRUMP, B. F.; TOLLERUD, D.; WESTON, A. \& HARRIS, C. C., 1990. Lung cancer and the debrisoquine metabolic phenotype. Journal of the National Cancer Institute, 82:1264-1272.

CASCORBI, I.; BROCKMÖLLER, J. \& ROOTS, I., 1996. A C4887A polymorphism in exon 7 of human CYP1A1: Population frequency, mutation linkages, and impact on lung cancer susceptibility. Cancer Research, 56:4965-4969.

CHARRIER, J.; MAUGARD, C. M.; LE MEVEL, B. \& BIGNON, Y. J., 1999. Allelotype influence at glutathione S-transferase M1 locus on breast cancer susceptibility. British Journal of Cancer, 79:346353.

CHEN, C. L.; LIU, Q.; PUI, C. H.; RIVERA, G. K.; SANDLUND, J. T.; RIBEIRO, R.; EVANS, W. E. \& RELLING, M. V., 1997. Higher frequency of glutathione Stransferase deletions in black children with acute lymphoblastic leukemia. Blood, 89:1701-1707.

CHEN, H.; SANDLER, D. P.; TAYLOR, J. A.; SHORE, D. L.; LIU, E.; BLOOMFIELD, C. D. \& BELL, D. A., 1996. Increased risk for myelodysplastic syndromes in individuals with glutathione transferase theta 1 (GSTT1) gene defect. Lancet, 347: 295-297.

COMMANDEUR, J. N.; STIJNTJES, G. J. \& VERMEULEN, N. P., 1995. Enzymes and transport systems involved in the formation and disposition of glutathione S-conjugates. Role in bioactivation and detoxication mechanisms of xenobiotics. Pharmacological Reviews, 47:271-330.

COSMA, G.; CROFTS, F.; CURRIE, D.; WIRGIN, I.; TONIOLO, P. \& GARTE, S. J., 1993. Racial differences in restriction fragment length polymorphisms and messenger RNA inducibility of the human CYP1Al gene. Cancer Epidemiology, Biomarkers and Prevention, 2:53-57.

CRESPI, C. L.; PENMAN, B.; GELBOIN, H. V. \& GONZALEZ, F. J., 1991. A tobacco smoke-derived nitrosamine, 4-(methylnitrosamino)-1-(3-pyridyl)1 -butanone, is activated by multiple human cytochrome P-450s including the polymorphic hu- 
man cytochrome P-4502D6. Carcinogenesis, 12: 1197-1201.

CROFTS, F.; COSMA, G. N.; CURRIE, D.; TAIOLI, E.; TONIOLO, P. \& GARTE, S. J., 1993. A novel CYP1A1 gene polymorphism in African-Americans. Carcinogenesis, 14:1729-1731.

CROFTS, F.; TAIOLI, E.; TRACHMAN, J.; COSMA, G. N.; CURRIE, D.; TONIOLO, P. \& GARTE, S. J., 1994. Functional significance of different human CYP1A1 genotypes. Carcinogenesis, 15:2961-2963.

CURRAN, J. E.; WEINSTEIN, S. R. \& GRIFFITHS, L. R., 2000. Polymorphism of glutathione S-transferase (GSTM1, GSTP1 and GSTT1) and breast cancer susceptibility. Cancer Letters, 153:113-120.

DEAKIN, M.; ELDER, J.; HENDRICKSE, C.; PECKHAM, D.; BALDWIN, D.; PANTIN, C.; WILD, N.; LEOPARD, P.; BELL, D. A.; JONES, P.; DUNCAN, H.; BRANNIGAN, K.; ALLDERSEA, J.; FRYER, A. A. \& STRANGE, R. C., 1996. Glutathione S-transferase GSTT1 genotypes and susceptibility to cancer: studies of interactions with GSTM1 in lung, oral, gastric and colorectal cancers. Carcinogenesis, 17:881-884

DOLL, R. \& PETO, R., 1981. The causes of cancer: Quantitative estimates of avoidable risks of cancer in the United States today. Journal of the $\mathrm{Na}$ tional Cancer Institute, 66:1191-1308.

EATON, D. L. \& BAMMLER, T. K., 1999. Concise review of the glutathione S-transferase and their significance to toxicology. Toxicology Science, 49:156164.

ELEXPURU-CAMIRUAGA, J.; BUXTON, N.; KANDULA, V.; DIAS, P. S.; CAMPBELL, D.; McINTOSH, J.; BROOMEM J.; JONES, P.; INSKIP, A.; ALLDERSEA, J.; FRYER, A. A. \& STRANGE, R. C., 1995. Susceptibility to astrocytoma and meningioma: Influence of allelism at glutathione S-transferase (GSTT1 and GSTM1) and cytochrome P-450 (CYP2D6) loci. Cancer Research, 55:4237-4239.

EL-ZEIN, R.; ZWISCHENBERGER, J. B.; WOOD, T. G.; ABDEL-RAHMAN, S. Z.; BREKELBAUM, C. \& AU, W. W., 1997. Combined genetic polymorphism and risk for development of lung cancer. Mutation Research, 381:189-200.

FOULKES, W. D.; BRUNET, J. S.; KOWALSKI, L. P.; NAROD, S. A. \& FRANCO, E. L., 1995. Family history of cancer is a risk factor for squamous cell carcinoma of the head and neck in Brazil: A casecontrol study. International Journal of Cancer, 63:769-773.

FRYER, A. A.; ZHAO, L.; ALLDERSEA, J.; PEARSON, W. R. \& STRANGE, R. C., 1993. Use of site-directed mutagenesis of allele-specific PCR primers to identify the GSTM1 A, GSTM1 B, GSTM1 AB and GSTM1 null polymorphisms at the glutathione Stransferase, GSTM1 locus. Biochemistry Journal, 295:313-315.

GARNIER, R.; RAMBOURG, S. M.; MULLER, A. \& HALLIER, E., 1996. Glutathione transferase activity and formation of macromolecular adducts in two cases of acute methyl bromide poisoning. Occupational and Environmental Medicine, 53: 211-215.

GONZALEZ, M. V.; ALVAREZ, V.; PELLO, M. F.; MENENDEZ, M. J.; SUAREZ, C. \& COTO, E., 1998. Genetic polymorphism of N-acetyltransferase-2, glutathione S-transferase-M1, and cytochromes P450IIE1 and P450IID6 in the susceptibility to head and neck cancer. Journal of Clinical Pathology, 51:294-298.

GOUGH, A. C.; SMITH, C. A. D.; HOWELL, S. M.; WOLF, C. R.; BRYANT, S. P. \& SPURR, N. K., 1993. Localization of the CYP2D gene locus to human chromosome 22q13.1 by polymerase chain reaction, in situ hybridization, and linkage analysis. Genomics, 15:430-432.

GOUGH, A. C.; ZHONG, S.; WOLF, C. R. \& SPURR, N. K., 1994. Chromosome assignment of the human glutathione $\mathrm{S}$-transferase mu gene specific polymerase chain reaction. Cytogenetics and Cell Genetics, 65:111-114.

HALLIER, E.; LANGHOF, T.; DANNAPPEL, D.; LEUTBECKER, M.; SCHROEDER, K. R.; GOERGENS, W.; MÜLLER, A. \& BOLT, H. M., 1993. Polymorphism of glutathione conjugation of methyl bromide, ethylene oxide and dichloro-methane in human blood: Influence on the induction of sister chromatid exchanges (SCE) in lymphocytes. Archives of Toxicology, 67:173-178.

HAMADA, G. S.; SUGIMURA, H.; SUZUKI, I.; NAGURA, K.; KIYOKAWA, E.; IWASE, T.; TANAKA, M.; TAKAHASHI, T.; WATANABE, S. \& KINO, I., 1995. The heme-binding region polymorphism of cytochrome P450IA1 (CypIA1), rather than the Rsa I polymorphism of IIE1 (CypIIE1), is associated with lung cancer in Rio de Janeiro. Cancer Epidemiology, Biomarkers and Prevention, 4:63-67.

HAND, P. A.; INSKIP, A.; GILFORD, J.; ALLDERSEA, J.; ELEXPURU-CAMIRUAGA, J.; HAYES, J. D.; JONES, P. W.; STRANGE, R. C. \& FRYER, A. A., 1996. Allelism at the glutathione S-transferase GSTM3 locus: Interactions with GSTM1 and GSTT1 as risk factors for astrocytoma. Carcinogenesis, 17:19192222.

HARIHARAN, N.; KELLEY, D. E.; PERRY, R. P., 1991. Delta, a transcription factor that binds to downstream elements in several polymerase II promoters, is a functionally versatile zinc finger protein. Proceedings of the National Academy of Science of the USA, 88:9799-9803.

HARRIES, L. W.; STUBBINS, M. J.; FORMAN, D.; HOWARD, G. C. \& WOLF, C. R., 1997. Identification of genetic polymorphisms at the glutathione S-transferase Pi locus and association with susceptibility to bladder, testicular and prostate cancer. Carcinogenesis, 18:641-644.

HARRIS, M. J.; COGGAN, M.; LANGTON, L.; WILSON, S. R. \& BOARD, P. G., 1998. Polymorphism of the pi class glutathione S-transferase in normal populations and cancer patients. Pharmacogenetics, 8:27-31.

HAYASHI, S.; WATANABE, J.; NAKACHI, K. \& KAWAJIRI, K., 1991a. Genetic polymorphisms of the lung cancer-associated Msp I polymorphisms with amino acid replacement in the heme binding region of the human cytochrome P450Al gene. Journal of Biochemistry, 110:407-411.

HAYASHI, S.; WATANABE, J. \& KAWAJIRI, K., 1991b. Genetic polymorphisms in the 5' flanking region change transcriptional regulation of the human cytochrome P450 IIE1 gene. Journal of Biochemistry, 100:559-564. 
HAYASHI, S.; WATANABE, J. \& KAWAJIRI, K., 1992. High susceptibility to lung cancer analysed in terms of combined genotypes of P4501A1 and $\mathrm{Mu}$-class glutathione S-transferase genes. Cancer Research, 83:866-870.

HAYES, J. D. \& PULFORD, D. J., 1995. The glutathione S-transferase supergene family. Regulation of GST and the contribution of the isoenzymes in cancer chemoprevention and drug resistance. Critical Reviews of the Biochemistry Molecular Biology, 30:445-600.

HEAGERTY, A. H. M.; FITZGERALD, D.; SMITH, A.; BOWERS, B.; JONES, P.; FRYER, A. A.; ZHAO, L.; ALLDERSEA, J. \& STRANGE, R. C., 1994. Glutathione S-transferase GSTM1 phenotypes and protection against cutaneous tumours. Lancet, 343:266-268.

HEAGERTY, A. H. M.; SMITH, A.; ENGLISH, J.; LEAR, J.; PERKINS, W.; BOWERS, B.; JONES, P.; GILFORD, J.; ALLDERSEA, J.; FRYER, A. A. \& STRANGE, R. C., 1996. Susceptibility to multiple cutaneous basal cell carcinomas: Significant interactions between glutathione S-transferase GSTM1 genotypes, skin type and male gender. British Journal of Cancer, 73:44-48.

HELLMOLD, H.; RYLANDER, T.; MAGNUSSON, M.; REIHNER, E.; WARNER, M. \& GUSTAFSSON, J. A., 1998. Characterization of cytochrome P450 enzymes in human breast tissue from reduction mammaplasties. Journal of Clinical Endocrinology and Metabolism, 83:886-895.

HELZLSOUER, K. J.; SELMIN, O.; HUANG, H. Y.; STRICKLAND, P. T.; HOFFMAN, S.; ALBERG, A. J.; WATSON, M.; COMSTOCK, G. W. \& BELL, D., 1998. Association between glutathione S-transferase $\mathrm{M} 1, \mathrm{P} 1$, and $\mathrm{T} 1$ genetic polymorphisms and development of breast cancer. Journal of the National Cancer Institute, 90:512-518.

HILDEBRAND, C. E.; GONZALEZ, F. J.; McBRIDE, O. W. \& NEBERT, D. W., 1985. Assignment of the human 2,3,7,8-tetrachlorodibenzo-p-dioxin-inducible cytochrome P1-450 gene to chromosome 15. Nucleic Acids Research, 13:2009-2016.

HIRVÖNEN, A.; HUSGAFVEL-PURSIAINEN, K.; ANTTILA, S.; KARJALAINEN, A. \& VAINIO, H., 1993. The human CYP2E1 gene and lung cancer: Dra I and Rsa I restriction fragment length polymorphisms in a Finnish study population. Carcinogenesis, 14:85-88.

HIRVÖNEN, A.; HUSGAFVEL-PURSIAINEN, K.; KARJALAINEN, A.; ANTTILA, S. \& VAINIO, H., 1992. Point-mutational MspI and Ile-Val polymorphisms closely linked in the CYP1A1 gene: Lack of association with susceptibility to lung cancer in a Finnish study population. Cancer Epidemiology, Biomarkers and Prevention, 1:485-489.

HUNG, H. C.; CHUANG, J.; CHIEN, Y. C.; CHERN, H. D.; CHIANG, C. P.; KUO, Y. S.; HILDESHEIM, A. \& CHEN, C. J., 1997. Genetic polymorphisms of CYP2E1, GSTM1, and GSTT1: Environmental factors and risk of oral cancer. Cancer Epidemiology, Biomarkers and Prevention, 6:901-905.

IDLE, J. R.; MAHGOUB, A.; LANCASTER, R. \& SMITH, R. L., 1978. Hypotensive response to debrisoquine and hydroxylation phenotype. Life Sciences, 22:979-984.
INGELMAN-SUNDBERG, M., 1998. Functional consequences of polymorphism of xenobiotic metabolising enzymes. Toxicology Letters, 102103:155-160.

INSKIP, A.; ELEXPERU-CAMIRUAGA, J.; BUXTON, N.; DIAS, P. S.; MacINTOSH, J.; CAMPBELL, D.; JONES, P. W.; YENGI, L.; TALBOT, A.; STRANGE, R. C. \& FRYER, A. A., 1995. Identification of polymorphism at the glutathione S-transferase, GSTM3 locus: Evidence for linkage with GSTM1*A. Biochemistry Journal, 312:713-716.

JAHNKE, V.; STRANGE, R.; MATTHIAS, C. \& FRYER, A., 1996. Glutathione S-transferase and cytochrome-P-450 polymorphism as risk factors for squamous cell carcinoma of the larynx. American Journal of Surgery, 172:671-673.

JOURENKOVA, N.; REINIKAINEN, M.; BOUCHARDY, C.; DAYER, P.; BENHAMOU, S. \& HIRVÖNEN, A., 1998. Larynx cancer risk in relation to glutathione $\mathrm{S}$-transferase $\mathrm{M} 1$ and $\mathrm{T} 1$ genotypes and tobacco smoking. Cancer Epidemiology, Biomarkers and Prevention, 7:19-23.

JOURENKOVA-MIRONOVA, N.; VOHO, A.; BOUCHARDY, C.; WIKMAN, H.; DAYER, P.; BENHAMOU, S. \& HIRVÖNEN, A., 1999. Glutathione S-Transferase GSTM3 and GSTP1 genotypes and larynx cancer risk. Cancer Epidemiology Biomarkers \& Prevention, 8:185-188.

JOURENKOVA-MIRONOVA, N.; WIKMAN, H.; BOUCHARDY, C.; VOHO, A.; DAYER, P.; BENHAMOU, S. \& HIRVÖNEN, A., 1998. Role of glutathione S-transferase GSTM1, GSTM3, GSTP1 and GSTT1 genotypes in modulating susceptibility to smoking-related lung cancer. Pharmacogenetics, 8:495-502.

KATO, S.; BOWMAN, E. D.; HARRINGTON, A. M.; BLOMEKE, B. \& SHIELDS, P. G., 1995. Human lung carcinogen-DNA adduct levels mediated by genetic polymorphisms in vivo. Journal of the $\mathrm{Na}$ tional Cancer Institute, 87:902-907.

KATO, S.; SHIELDS, P. G.; CAPORASO, N. E.; HOOVER, R. N.; TRUMP, B. F.; SUGIMURA, H.; WESTON, A. \& HARRIS, C. C., 1992. Cytochrome P450IIE1 genetic polymorphisms, racial variation and lung cancer risk. Cancer Research, 52:6712-6715.

KAWAJIRI, K.; NAKACHI, K.; IMAI, K.; WATANABE, J.; HAYASHI, S., 1993. The CYP1A1 gene and cancer susceptibility. Critical Reviews in Hematologic Oncology, 14:77-87.

KAWAJIRI, K.; NAKACHI, K.; IMAI, K.; YOSHII, A.; SHINODA, N. \& WATANABE, J., 1990. Identification of genetically high risk individuals to lung cancer by DNA polymorphisms of the cytochrome P450IA1 gene. FEBS Letters, 263:131-133.

KELLERMANN, G.; LUYTE-KELLERMANN, M. \& SHAW, C. R., 1973. Genetic variation of aryl hydrocarbon hydroxylase in human lymphocytes. American Journal of Human Genetics, 25:327-331.

KELLEY, M. K.; ENQVIST-GOLDSTEIN, A.; MONTALI, J.; WHEATLEY, J. B.; SCHMIDT Jr., D. E. \& KAUAR, L. M., 1994. Variability of glutathione S-transferase isoenzyme patterns in matched normal and cancer breast human tissue. Biochemical Journal, 304:843-848.

KELSEY, K. T. \& WIENCKE, J. K., 1998. Growing pains for the environmental genetics of breast cancer: 
Observations on a study of the glutathione Stransferases. Journal of the National Cancer Institute, 90:484-486.

KEMPKES, M.; GOLKA, K.; REICH, S.; RECKWITZ, T. \& BOLT, H. M., 1996. Glutathione S-transferase GSTM1 and GSTT1 null genotypes as potential risk factors for urothelial cancer of the bladder. Archives of Toxicology, 71:123-126.

KIHARA, M.; KIHARA, M. \& NODA, K., 1995. Risk of smoking for squamous and small cell carcinomas of the lung modulated by combinations of CYP1A1 and GSTM1 gene polymorphisms in a Japanese population. Carcinogenesis, 16:2331-2336.

KOLBLE, K., 1993. Regional mapping of short tandem repeats on human chromosome 10: Cytochrome P450 gene CYP2E, D10S196, D10S220, and D10S225. Genomics, 18:702-704.

KOURI, R. E.; McKINNEY, C. E.; SLOMIANY, D. J.; SNODGRASS, D. R.; WRAY, N. P. \& McLEMORE, T. L., 1982. Positive correlation between high aryl hydrocarbon hydroxylase activity and primary lung cancer as analyzed in cryopreserved lymphocytes. Cancer Research, 42:5030-5037.

KRISTENSEN, V. N.; ANDERSEN, T. I.; ERIKSTEIN, B.; GEITVIK, G.; SKOVLUND, E.; NESLAND, J. M. \& BORRESEN-DALE, A. L., 1998. Single tube multiplex polymerase chain reaction genotype analysis of GSTM1, GSTT1 and GSTP1: Relation of genotypes to TP53 tumor status and clinicopathological variables in breast cancer patients. Pharmacogenetics, 8:441-447.

LAISNEY, V.; VAN CONG, N.; GROSS, M. S. \& FREZAL, J., 1984. Human genes for glutathione S-transferases. Human Genetics, 68:221-227.

LAN, Q.; HE, X.; COSTA, D. J.; TIAN, L.; ROTHMAN, N.; HU, G., \& MUMFORD, J. L., 2000. Indoor coal combustion emissions, GSTM1 and GSTT1 genotypes, and lung cancer risk: A case-control study in Xuan Wei, China. Cancer Epidemiology, Biomarkers and Prevention, 9:605-608.

LANDI, S., 2000. Mammalian class theta GST and differential susceptibility to carcinogens: A review. Mutation Research, 463:247-283.

LE MARCHAND, L.; SIVARAMAN, L.; PIERCE, L.; SEIFRIED, A.; LUM, A.; WILKENS, L. R. \& LAU, A. F., 1998. Associations of CYP1A1, GSTM1, and CYP2E1 polymorphisms with lung cancer suggest cell type specificities to tobacco carcinogens. Cancer Research, 58:4858-4863.

LIN, D. X.; TANG, Y. M.; PENG, Q.; LU, S. X.; AMBROSONE, C. B. \& KADLUBAR, F. F., 1998. Susceptibility to esophageal cancer and genetic polymorphisms in glutathione S-transferases T1, P1, and $\mathrm{M} 1$ and cytochrome P450 2E1. Cancer Epidemiology, Biomarkers and Prevention, 7:1013-1018.

LIU, Y. H.; TAYLOR, J.; LINKO, P.; LUCIER, G. W. \& THOMPSON, C. L., 1991. Glutathione S-transferase mu in human lymphocyte and liver: Role in modulating formation of carcinogen-derived DNA adducts. Carcinogenesis, 12:2269-2275.

MANNERVIK, B., 1985. The isoenzymes of glutathione transferase. In: Advances in Enzymology (A. Meister, ed.), v. 57, pp. 357-417, New York: Wiley and Sons.

MATTHIAS, C.; BOCKMÜHL, U.; JAHNKE, V.; JONES, P. W.; HAYES, J. D.; ALLDERSEA, J.; GILFORD, J.;
BAILEY, L.; BATH, J.; WORRALL, S. F.; HAND, P.; FRYER, A. A. \& STRANGE, R. C., 1998. Polymorphisms in cytochrome P450 CYP2D6, CYP1A1, CYP2E1 and glutathione S-transferase, GSTM1, GSTM3, GSTT1 and susceptibility to tobacco-related cancers: Studies in upper aerodigestive tract cancers. Pharmacogenetics, 8:91-100.

MAUGARD, C. M.; CHARRIER, J.; \& BIGNON, Y. J., 1998. Allelic deletion at glutathione S-transferase M1 locus and its association with breast cancer susceptibility. Chemico-Biological Interactions, 111-112:365-375.

MITRUNEN, K.; JOURENKOVA, N.; KATAJA, V.; ESKELINEN, M.; KOSMA, V. M.; BENHAMOU, S.; VAINIO, H.; UUSITUPA, M. \& HIRVÖNEN, A., 2001. Glutathione S-Transferase M1, M3, P1, and $\mathrm{T} 1$ genetic polymorphisms and susceptibility to breast cancer. Cancer Epidemiology, Biomarkers and Prevention, 10:229-236.

MORITA, S.; YANO, M.; SHIOZAKI, H.; TSUJINAKA, T; EBISUI, C.; MORIMOTO, T.; KISHIBUTI, M.; FUJITA, J.; OGAWA, A.; TANIGUCHI, M.; INOUE, M.; TAMURA, S.; YAMAZAKI, K.; KIKKAWA, N.; MIZUNOYA, S. \& MONDEN, M., 1997. CYP1A1, CYP2E1 and GSTM1 polymorphisms are not associated with susceptibility to squamous-cell carcinoma of the esophagus. International Journal of Cancer, 71:192-195.

MORROW, C. S. \& COWAN, K. H., 1990. Glutathione $\mathrm{S}$-transferases and drug resistance. Cancer Cells, 2:15-22.

MOSCOW, J. A.; TOWNSEND, A. J.; GOLDSMITH, M. E.; WHANG-PENG, J.; VICKERS, P. J.; POISSON, R.; LEGAULT-POISSON, S.; MYERS, C. E. \& COWAN, K. H., 1988. Isolation of the human anionic glutathione S-transferase cDNA and the relation of its gene expression to estrogen-receptor content in primary breast cancer. Proceedings of the National Academy of Sciences of the USA, 85:65186522.

NAIR, U. J.; NAIR, J.; MATTHEW, B. \& BARTSCH, H., 1999. Glutathione S-transferase M1 and T1 null genotypes as risk factors for oral leukoplakia in ethnic Indian betel quid/tobacco chewers. Carcinogenesis, 20:743-748.

NAKACHI, K.; IMAI, K.; HAYASHI, S. \& KAWAJIRI, K., 1993. Polymorphisms of the CYP1A1 and glutathione S-transferase genes associated with susceptibility to lung cancer in relation to cigarette dose in a Japanese population. Cancer Research, 53:2994-2999.

NAKACHI, K.; IMAI, K.; HAYASHI, S.; WATANABE, J. \& KAWAJIRI, K., 1991. Genetic susceptibility to squamous cell carcinoma of the lung in relation to cigarette smoking dose. Cancer Research, 51:51775180.

NAKAJIMA, T.; ELOVAARA, E.; ANTILLA, S.; HIRVÖNEN, A.; CAMUS, A. M.; HAYES, J. D.; KETTERER, B. \& VAINIO, H., 1995. Expression and polymorphism of glutathione S-transferase in human lungs: Risk factors in smoking-related lung cancer. Carcinogenesis, 16:707-711.

NEBERT, D. W., 1991. Role of genetics and drug metabolism in human cancer risk. Mutation Research, 247:267-281.

NEBERT, D. W., 1997. Polymorphisms in drug-metab- 
olizing enzymes: What is their clinical relevance and why do they exist? American Journal of Human Genetics, 60:265-271.

NEBERT, D. W. \& GONZALEZ, F. J., 1987. P450 genes: Structure, evolution, and regulation. Annual Review of Biochemistry, 56:945-993.

NEDELCHEVA, V.; PERSSON, I. \& INGELMAN-SUNDBERG, M., 1996. Genetic polymorphism of human cytochrome P450 2E1. Methods in Enzymology, 272:216-225.

NELSON, S. A.; WIENCKE, J. K.; CHRISTIANI, D. C.; CHENG, T. J.; ZUO, Z. H. F.; SCHWARTZ, B. S.; LEE, B. K.; SPITZ, M. R.; WANG, M.; XU, X. P. \& KELSEY, K. T., 1995. Ethnic differences in the prevalence of the homozygous deleted genotype of glutathione S-transferase theta. Carcinogenesis, 16:1243-1245.

NYBERG, F.; HOU, S. M.; HEMMINKI, K.; LAMBERT, B. \& PERSHAGEN, G., 1998. Glutathione S-transferase $\mathrm{ml}$ and $\mathrm{N}$-acetyltransferase 2 genetic polymorphisms and exposure to tobacco smoke in nonsmoking and smoking lung cancer patients and population controls. Cancer Epidemiology, Biomarkers and Prevention, 7:875-883.

OKINO, S. T.; QUATTROCHI, L. C.; PENDURTHI, U. R.; McBRIDE, O. W, \& TUKEY, R. H., 1987. Characterization of multiple human cytochrome P-450 1 cDNAs: The chromosomal localization of the gene and evidence for alternate RNA splicing. Journal of Biological Chemistry, 262:16072-16079.

OLSHAN, A. F.; WEISSLER, M. C.; WATSON, M. A. \& BELL, D. A., 2000. GSTM1, GSTT1, GSTP1, CYP1A1 and NAT1 polymorphisms, tobacco use, and the risk of head and neck cancer. Cancer Epidemiology, Biomarkers and Prevention, 9:185-191.

PARK, J. Y.; MUSCAT, J. E.; REN, Q.; SCHANTZ, S. P.; HARWICK, R. D.; STERN, J. C.; PIKE, V.; RICHIE Jr., J. P. \& LAZARUS, P., 1997. CYP1A1 and GSTM1 polymorphisms and oral cancer risk. Cancer Epidemiology, Biomarkers and Prevention, 6:791-797.

PARK, S. K.; YOO, K. Y.; LEE, S. J; KIM, S. U.; AHN, S. H.; NOH, D. Y.; CHOE, K. J.; STRICKLAND, P. T.; HIRVÖNEN, A. \& KANG, D., 2000. Alcohol consumption, glutathione S-transferase M1 and T1 polymorphisms and breast cancer risk. Pharmacogenetics, 10:301-309.

PARKINSON, A., 1996. Biotransformation of xenobiotics. In: Casarett \& Doull's Toxicology. The Basic Science of Poisons (C. D. Klaassen, ed.), v. 6, pp. 113-186, 5th Ed. New York/Saint Louis/San Francisco: McGraw-Hill.

PAVANELLO, S. \& CLONFERO, E., 2000. Biological indicators of genotoxic risk and metabolic polymorphisms. Mutation Research/Reviews in Mutation Research, 463:285-308.

PEARSON, W. R.; VORACHEK, W. R.; XU, S.; BERGER, R.; HART, I.; VANNAIS, D. \& PATTERSON, D., 1993. Identification of class-mu glutathione transferase genes GSTM1-GSTM5 on human chromosome 1p13. American Journal of Human Genetics, 53:220-223.

PEMBLE, S.; SCHROEDER, K. R.; SPENCER, S. R.; MEYER, D. J.; HALLIER, E.; BOLT, H. M.; KETTERER, B. \& TAYLOR, J. B., 1994. Human glutathione S-transferase theta (GSTT1): cDNA cloning and the characterization of a genetic polymorphism.
Biochemistry Journal, 300:271-276.

PERERA, F. P., 1997. Environment and cancer: Who are susceptible? Science, 278:1068-1073.

PERSSON, I.; JOHANSSON, I.; BERGLING, H.; DAHL, M. L.; SEIDEGARD, J.; RYLANDER, R.; RANNUG, A.; HOGBERG, J. \& INGELMAN-SUNDBERG, M., 1993. Genetic polymorphism of cytochrome P4502E1 in a Swedish population - Relationship to incidence of lung cancer. FEBS Letters, 319:207211.

PESSAH-RAMUSSEN, H.; STAVENOW, L.; SEIDEGARD, J. \& BERGLUND, A., 1992. Human fibroblasts lacking trans-stilbene oxide active glutathione exhibit increased cell death when exposed to polycyclic aromatic hydrocarbons. Pharmacology and Toxicology, 70:361-365.

PICKETT, C. B. \& LU, A. Y. H., 1989. Glutathione Stransferases: Gene structure, regulation, and biological function. Annual Review of Biochemistry, 58:743-764.

PRESTON-MARTIN, S.; PIKE, M. C.; ROSS, R. K.; JONES, P. A. \& HENDERSON, B. E., 1990. Increased cell division as a cause of human cancer. Cancer Research, 50:7415-7421.

RAUNIO, H.; HUSGAFVEL-PURSIAINEN, K.; ANTTILA, S.; HIETANEN, E.; HIRVÖNEN, A. \& PELKONEN, O., 1995. Diagnosis of polymorphisms in carcinogen-activating and inactivating enzymes and cancer susceptibility - A review. Gene, 159:113-121.

RODDAM, P. L.; ROLLINSON, S.; KANE, E.; ROMAN, E.; MOORMAN, A.; CARTWRIGHT, R. \& MORGAN, G. J., 2000. Poor metabolizers at the cytochrome P450 2D6 and 2C19 loci are at increased risk of developing adult acute leukaemia. Pharmacogenetics, 10:605-615.

ROMKES, M.; WHITE, C.; JOHNSON, J.; EIBLING, D. \& BRANCH, R., 1996. Expression of cytochrome P450 mRNA in human lung, head and neck tumors, and normal adjacent tissue. Proceedings of the American Association for Cancer Research, $37: 105$.

ROOTS, I.; DRAKOULIS, N.; PLOCH, M.; HEINMEYER, G.; LODDENKEMPER, R.; MINKS, T.; NITZ, M.; OTTE, F. \& KOCH, M., 1988. Debrisoquine hydroxylation phenotype, acetylation phenotype, and $\mathrm{ABO}$ blood groups as genetic host factors of lung cancer risk. Klinische Wochenschrift, 66(Sup. 11):87-97.

RYBERG, D.; SKAUG, V.; HEWER, A.; PHILLIPS, D. H.; HARRIES, L. W.; WOLF, C. R.; ØGREID, D.; ULVIK, A.; VU, P. \& HAUGEN, A., 1997. Genotypes of glutathione transferase $\mathrm{M} 1$ and $\mathrm{P} 1$ and significance for lung DNA adduct levels and cancer risk. Carcinogenesis, 18:1285-1289.

SACHSE, C.; BROCKMÖLLER, J.; BAUER, S. \& ROOTS, I., 1997. Cytochrome P450 2D6 variants in a Caucasian population: Allele frequencies and phenotypic consequences. American Journal of Human Genetics, 60:284-295.

SATO, M.; SATO, T.; IZUMO, T. \& AMAGASA, T., 2000. Genetically high susceptibility to oral squamous cell carcinoma in terms of combined genotyping of CYP1A1 and GSTM1 genes. Oral Oncology, 26:267-271.

SCARPATO, R.; HIRVÖNEN, A.; MIGLIORE, L.; FALCK, 
G. \& NORPPA, H., 1997. Influence of GSTM1 and GSTT1 polymorphisms on the frequency of chromosome aberrations in smokers and pesticideexposed greenhouse workers. Mutation Research, 389:227-235.

SEIDEGARD, J.; PERO, R. W.; MARKOWITZ, M. M.; ROUSH, G.; MILLER, D. G. \& BEATTIE, E. J., 1990. Isoenzyme(s) of glutathione transferase (class $\mathrm{Mu}$ ) as a marker for the susceptibility to lung cancer: A follow up study. Carcinogenesis, 11:33-36.

SEIDEGARD, J.; PERO, R. W.; MILLER, D. G. \& BEATTIE, E. J., 1986. A glutathione transferase in human leukocytes as a marker for the susceptibility to lung cancer. Carcinogenesis, 7:751-753.

SEIDEGARD, J.; VORACHEK, W. R.; PERO, R. W. \& PEARSON, W. R., 1988. Hereditary differences in the expression of the human glutathione transferase active on trans-stilbene oxide are due to a gene deletion. Proceedings of the National Academy of Sciences of the USA, 85:7293-7297.

SHIELDS, P. G.; BOWMAN, E. D.; HARRINGTON, A. M.; DOAN, V. T. \&WESTON, A., 1993. Polycyclic aromatic hydrocarbon-DNA adducts in human lung and cancer susceptibility genes. Cancer Research, 53:3486-3492.

SIVARAMAN, L.; LEATHAM, M. P.; YEE, J.; WILKENS, L. R.; LAU, A. F. \& LE MARCHAND, L., 1994. CYP1A1 genetic polymorphisms and in situ colorectal cancer. Cancer Research, 54:3692-3695.

SMITH, C. A. D.; GOUGH, A. C.; LEIGH, P. N.; SUMMERS, B. A.; HARDING, A. E.; MARANGANORE, D. M.; STURMAN, S. G.; SCHAPIRA, A. H. V.; WILLIAMS, A. C.; SPURR, N. K. \& WOLF, C. R., 1992. Debrisoquine hydroxylase gene polymorphism and susceptibility to Parkinson's disease. Lancet, 339:1375-1377.

SMITH, G.; STANLEYM, L. A.; SIM, E.; STRANGE, R. C. \& WOLF, C. R., 1995. Metabolic polymorphisms and cancer susceptibility. Cancer Surveys, 25:2765.

SORSA, M.; OSTERMANGOLKAR, S.; PELTONEN, K.; SAARIKOSKI, S. T. \& SRAM, R., 1996. Assessment of exposure to butadiene in the process industry. Toxicology, 113:77-83.

STRANGE, R. C.; LEAR, J. T. \& FRYER, A. A., 1998. Glutathione S-transferase polymorphisms: Influence on susceptibility to cancer. Chemico-Biological Interactions, 111-112:351-364.

STRANGE, R. C.; MATHAROO, B.; FAULDER, C. G.; JONES, P.; COTTON, W.; ELDER, J. B. \& DEAKIN, M., 1991. The human glutathione S-transferase: A case-control study of the incidence of the GST1 0 phenotype in patients with adenocarcinoma. Carcinogenesis, 12:25-28.

SUNDBERG, K.; JOHANSSON, A. S.; STENBERG, G.; WIDERSTEN, M.; SEIDEL, A.; MANNERVIK, B. \& JERNSTROM, B., 1998. Differences in the catalytic efficiencies of allelic variants of glutathione transferase P1-1 towards carcinogenic diol epoxides of polycyclic aromatic hydrocarbons. Carcinogenesis, 19:433-436.

SUGIMURA, H.; HAMADA, G. S.; SUZUKI, I.; IWASE, T.; KIYOKAWA, E.; KINO, I. \& TSUGANE, S., 1995. CYP1A1 and CYP2E1 polymorphism and lung cancer, case-control study in Rio de Janeiro, Brazil. Pharmacogenetics, 5:S145-S148.
SUGIMURA, H.; WAKAI, K.; GENKA, K.; NAGURA, K.; IGARASHI, H.; NAGAYAMA, K.; OHKAWA, A.; BABA, S.; MORRIS, B. J.; TSUGANE, S.; OHNO, Y.; GAO, C.; LI, Z.; TAKEZAKI, T.; TAJIMA, K. \& IWAMASA, T., 1998. Association of Ile462Val (exon 7) polymorphism of cytochrome P450 IA1 with lung cancer in the Asian population: Further evidence from a case-control study in Okinawa. Cancer Epidemiology, Biomarkers and Prevention, 7:413-417.

SUZUKI, T.; COGGAN, M.; SHAW, D. V. \& BOARD, P. G., 1987. Electrophoretic and immunological analysis of human glutathione S-transferase isozymes. Annals of Human Genetics, 51:95-106.

TAIOLI, E.; TRACHMAN, J.; CHEN, X.; TONIOLO, P., \& GARTE, S. J., 1995. A CYP1A1 restriction fragment length polymorphism is associated with breast cancer in African-American women. Cancer Research, 55:3757-3758.

TAKAHASHI, Y.; CAMPBELL, E. A.; HIRATA, Y.; TAKAYAMA, T. \& LISTOWSKY, I., 1993. A basis for differentiating among the multiple human $\mathrm{Mu}-$ glutathione S-transferase and molecular cloning of brain GSTM5. Journal of Biological Chemistry, 268:8893-8898.

TAN, W.; SONG, N.; WANG, G. Q.; LIU, Q.; TANG, H. J.; KADLUBAR, F. F. \& LIN, D. X., 2000. Impact of genetic polymorphisms in cytochrome P450 2E1 and glutathione S-transferases $\mathrm{M} 1, \mathrm{~T} 1$, and $\mathrm{P} 1$ on susceptibility to esophageal cancer among highrisk individuals in China. Cancer Epidemiology, Biomarkers and Prevention, 9:551-556.

TANIMOTO, K.; HAYASHI, S.; YOSHIGA, K. \& ICHIKAWA, T., 1999. Polymorphisms of the CYP1A1 and GSTM1 gene involved in oral squamous cell carcinoma in association with a cigarette dose. Oral Oncology, 35:191-196.

TANINGHERA, M.; MALACARNEA, D.; IZZOTTIB, A.; UGOLINIA, D. \& PARODIA, S., 1999. Drug metabolism polymorphisms as modulators of cancer susceptibility. Mutation Research/Reviews in $\mathrm{Mu}$ tation Research. 436:227-261.

TAYLOR, J. B.; OLIVER, J.; PEABLE, S. E. \& KETTERER, B., 1990. Structural relationships of human class mu glutathione S-transferase genes: Evidence for gene conversion and for sub-division of the class. In: Glutathione S-Transferases and Drug Resistance (J. D. Hayes, C. B. Pickett \& T. J. Mantle, ed.), pp. 242-249, London: Taylor \& Francis.

TEFRE, T.; RYBERG, D.; HAUGEN, A.; NEBERT, D. W.; SKAUG, V.; BROGGER, A. \& BORRESEN, A. L., 1991. Human CYP1Al (cytochrome P1450) gene: Lack of association between the MspI restriction fragment length polymorphism and incidence of lung cancer in a Norwegian population. Pharmacogenetics, 1:20-25.

TEW, K. D., 1994. Glutathione-associated enzymes in anticancer drug resistance. Cancer Research, 54:4313-4320.

TO-FIGUERAS, J.; GENE, M.; GOMEZ-CATALAN, J.; GALAN, M. C.; FUENTES, M.; RAMON, J. M.; RODAMILANS, M.; HUGUET, E. \& CORBELLA, J., 1997. Glutathione S-transferase M1 (GSTM1) and T1 (GSTT1) polymorphisms and lung cancer risk among Northwestern Mediterraneans. Carcinogenesis, 18:1529-1533.

TRELL, L.; KORSGAARD, R.; JANZON, L. \& TRELL, E., 
1985. Distribution and reproducibility of aryl hydrocarbon hydroxylase inducibility in a prospective study of middle-aged male smokers and nonsmokers. Cancer, 56:988-994.

TSUCHIDA, S. \& SATO, K., 1992. Glutathione transferases and cancer. Critical Reviews of the Biochemistry Molecular Biology, 27:337-384.

VAN LIESHOUT, E. M.; ROELOFS, H. M.; DEKKER, S.; MULDER, C. J.; WOBBES, T.; JANSEN, J. B. \& PETERS, W. H., 1999. Polymorphic expression of the glutathione S-transferase P1 gene and its susceptibility to Barrett's esophagus and esophageal carcinoma. Cancer Research, 59:586-589.

VAN POPPEL, G.; VOGEL, N.; VAN BLADEREN, P. J. \& KOK, J. K., 1992. Increased cytogenetic damage in smokers deficient in glutathione S-transferase isozyme mu. Carcinogenesis, 13:303-305.

VORACHEK, W. R.; PEARSON, W. R. \& RULE, G. S., 1991. Cloning, expression, and characterization of a class-mu glutathione transferase from human muscle, the product of the GST4 locus. Proceedings of the National Academy of Sciences of the USA, 88:4443-4447.

WATSON, M. A.; STEWART, R. K.; SMITH, G. B.; MASSEY, T. E. \& BELL, D. A., 1998. Human glutathione S-transferase P1 polymorphisms: Relationship to lung tissue enzyme activity and population frequency distribution. Carcinogenesis 19: 275-280.

WEBB, G.; VASKA, V.; COGGAN, M. \& BOARD, P., 1996. Chromosomal localization of the gene for the human theta class glutathione transferase (GSTT1). Genomics, 33:121-123.

WORRALL, S. F.; CORRIGAN, M.; HIGH, A.; STARR, D.; MATTHIAS, C.; WOLF, C. R.; JONES, P. W.; HAND, P.; GILFORD, J.; FARRELL, W. E.; HOBAN, P.; FRYER, A. A. \& STRANGE, R. C., 1998. Susceptibility and outcome in oral cancer: Preliminary data showing an association with polymorphism in cytochrome P450 CYP2D6. Pharmacogenetics, 8:433-439.

XU, X. P.; KELSEY, K. T.; WIENCKE, J. K.; WAIN, J. C. \& CHRISTIANI, D. C., 1996. Cytochrome P450 CYP1A1 MspI polymorphism and lung cancer susceptibility. Cancer Epidemiology, Biomarkers and Prevention, 5:687-692.
XU, X. P.; WIENCKE, J. K.; NIU, T. H.; WANG, M.; WATANABE, H.; KELSEY, K. T. \& CHRISTIANI, D. C., 1998. Benzene exposure, glutathione S-transferase theta homozygous deletion, and sister chromatid exchanges. American Journal of Industrial Medicine, 33:157-163.

YENGI, L.; INSKIP, A.; GILFORD, J.; ALLDERSEA, J.; BAILEY, L.; SMITH, A.; LEAR, J. T.; HEAGERTY, A. H.; BOWERS, B.; HAYES, J. D.; JONES, P. W.; STRANGE, R. C. \& FRYER, A. A., 1996. Polymorphism at the glutathione S-transferase locus GSTM3: Interactions with cytochrome P450 and glutathione S-transferase genotypes as risk factors for multiple cutaneous basal cell carcinoma. Cancer Research, 6:1974-1977.

ZHONG, S.; SPURR, N. K.; HAYES, J. D. \& WOLF, C. R., 1993a. Deduced amino acid sequence, gene structure and chromosomal location of a novel human class Mu glutathione S-transferase, GSTM4. Biochemical Journal, 291:41-50.

ZHONG, S.; WOLF, C. R. \& SPURR, N. K., 1992. Chromosomal assignment and linkage analysis of the human glutathione S-transferase m gene (GSTM1) using intron specific polymerase chain reaction. Human Genetics, 90:435-439.

ZHONG, S.; WYLLIE, A. H.; BARNES, D.; WOLF, C. R. \& SPURR, N. K. 1993b. Relationship between the GSTM1 genetic polymorphism and susceptibility to bladder, breast and colon cancer. Carcinogenesis, 14:1821-1824.

ZIMNIAK, P.; NANDURI, B.; PIKULA, S.; BANDOROWICZ-PIKULA, J.; SINGHAL, S.; SRIVASTAVA, S. K.; AWASTHI, S. \& AWASTHI, Y. C., 1994. Naturally occurring human glutathione S-transferase GSTP1-1 isoforms with isoleucine and valine in position 104 differ in enzymic properties. European Journal of Biochemistry, 224:893-899.

Submitted on 22 January 2001

Final version resubmitted on 25 July 2001

Approved on 20 August 2001 